Chapter 16

\title{
Equidae from the Baynunah Formation
}

Raymond L. Bernor ${ }^{1}$, Mark Beech ${ }^{2}$, and Faysal Bibi ${ }^{3}$

1. College of Medicine, Department of Anatomy, Laboratory of Evolutionary Biology, Howard University, Washington DC, USA. rbernor@howard.edu.

2. Coastal Heritage and Palaeontology Section, Historic Environment, Abu Dhabi Tourism and Culture Authority, TCA Abu Dhabi, UAE.

3. Museum für Naturkunde, Leibniz Institute for Evolution and Biodiversity Science, Invalidenstrasse 43, Berlin, Germany 10115.

Abstract-We report 87 specimens of hipparionine horse from the Baynunah Formation, United Arab Emirates. The dominate species is referred to "Hipparion" abudhabiense. "Hipparion" abudhabiense is represented by mandibles, mandibular and maxillary cheek teeth and a variety of postcranial bones, some of which are complete. Baynunah Formation early wear cheek teeth suggest that "Hipparion" abudhabiense was higher crowned than Central European Hippotherium primigenium with a maximum crown height of 60-65 mm. AUH 270, the type mandible is characterized as having a short, broad symphysis with horizontally aligned incisors. While the previous view was that this mandible suggested an evolutionary relationship with Greek Hipparion dietrichi, a fragmentary but otherwise elongate metacarpal III (AUH 1499) exhibits a close similarity to Akkasdagi (7.1 Ma) and Calta (4.0 Ma) "Plesiohipparion" cf. longipes. There is a rare, smaller species of hipparion that compares favorably in its size and morphology to Greek and Iranian members of the Cremohipparion matthewi-nikosi lineage. The Baynunah hipparion fauna supports a correlation of ca. $7 \mathrm{Ma}$, and a potential biogeographic affinity with Greece, Turkey, Iran and possibly Northern Kazakhstan.

Running Head: Equidae 


\section{Introduction}

Fossils of hipparionin equids have been collected from the Baynunah Formation of Abu Dhabi Emirate for over 30 years. Most notably, a joint Natural History Museum, London - Yale University research team led by Peter Whybrow and Andrew Hill respectively, was active from 1986-1994, and a Yale-ADACH (Abu Dhabi Authority for Culture and Heritage, currently the Department of Tourism and Culture) project has been active since 2006 (Hill 1999; Hill et al. 2012; Bibi et al. 2013, this volume-a; Beech et al. this volume). Over 30 years, some 197 specimens of fossil hipparion, many of which are fragmentary, have been collected from the late Miocene Baynunah Formation, UAE (Fig. 16.1). Eisenmann and Whybrow (1999) reported 41 specimens of "Hipparion" including maxillary and mandibular teeth, limb bones and fragmentary mandibles. The authors recognized two "Hipparion" taxa, one small or middle sized, and one larger. The current study is based on 84 specimens that have varying degrees of diagnostic characters. Table 16.1 provides a list of Baynunah hipparion specimens with Bernor et al.'s (this contribution) species determinations and Eisenmann and Whybrow's (1999) species determinations. Differences between these two are due largely to size subjectivity. Table 16.2 gives measurements on our sample of the Baynunah hipparions.

\section{FIGURE 16.1 NEAR HERE. ONE COLUMN WIDTH}

\section{Methods}

Statistical analysis - Systat 12 was used to calculate bivariate plots of calcaneum, astragalus, metacarpal III, metatarsal III and 1st Phalanx III using the Höwenegg sample of Hippotherium primigenium as a standard for calculating $95 \%$ confidence ellipses.

\footnotetext{
Abbreviations and conventions-Ma: mega-annum in the geochronologic time scale. Ages in m.y. usually based on radioisotopic analyses or magnetostratigraphic analyses. North Africa: localities may be referred to the MN biochronologic time scale. Western Eurasia: Vallesian, Turolian, and Ruscinian; intervals of the European land mammal age sequence, commonly termed units (sensu Fahlbusch
} 
1991). Measurement Table Abbreviations Sex: $M=$ male; $F=$ female; ? = unknown. Sex can be defined by the size of a canine tooth, male being large, female being small.

Side: 1 t. $=$ left; rt. $=$ right .

Element abbreviations $-\mathrm{CALC}=$ calcaneum; $\mathrm{AST}=$ astragalus; $\mathrm{MCIII}=$ metacarpal III; MTIII $=$ metatarsal III; MPIII = metapodial III; 1 PHIII = 1st phalanx III and $2 \mathrm{PHIII}=2$ nd phalanx III (central digit) of either the anterior or posterior limb, which are difficult to distinguish in hipparion. Maxillary tooth - uppercase (I, C, P or M); mandibular tooth - lower case (i, c, p or m).

Systat plot abbreviations-M1-M38 refers to measurements as described by Eisenmann et al. (1988) and Bernor et al. (1997). Bernor et al. (2016) and Bernor and Sen (2017) have recently considered these taxa and have reviewed them accordingly.

References given below include measurements of those samples. Statistical plots include abbreviations by locality. These abbreviations are as follows:

$\mathrm{a}=$ Akkasdagi, Turkey (7.1 Ma) Koufos \& Vlachou (2005), Scott \& Maga (2005), Bernor \& Sen (2017)

$\mathrm{b}=$ Sahabi, Libya (ca. $7 \mathrm{Ma})$ Bernor et al. (2012)

C = China Plesiohipparion spp, (5-2.5 Ma) Bernor \& Sun (2015), Bernor et al. (2015)

$\mathrm{D}=$ Baynunah (ca. $7 \mathrm{Ma})$ this manuscript

e = Ethiopia (6-3 Ma) Bernor et al. (2009)

$\mathrm{g}$ = Germany (Höwenegg, 10.3 Ma (Bernor et al. 1997); Eppelsheim, $10 \mathrm{Ma}$ )

k = Pikermi, Greece (8 Ma) Koufos (1987)

m = Maragheh, Iran (9-7.4 Ma) Bernor (1985), Bernor et al. (2016)

$\mathrm{n}=$ Sinap, Turkey (10.6-9.7 Ma) Bernor et al. (2003)

$\mathrm{p}=$ Pakistan (10.5-7 Ma) Wolf et al. (2013)

$\mathrm{t}=$ Tanzania (5-1 Ma) Armour-Chelu \& Bernor (2011)

$\mathrm{w}=$ Perpignan, France (3.5 Ma) Bernor $\&$ Sen (2017) 
$\mathrm{y}=$ Kenya (10-5 Ma) Bernor \& Harris (2003)

$\mathrm{Z}=$ Çalta, Turkey Proboscidipparion (4.0 Ma) Bernor \& Sen (2017)

z = Çalta, Turkey “Plesiohipparion” (4.0 Ma) Bernor \& Sen (2017)

Taxonomic abbreviations used in log10 plots - AL- Hadar, Denen Dora Member Eurygnathohippus hasumense; AK_Mean - Akkasdagi “Plesiohipparion” cf. longipes; AUH - Baynunah hipparion; BH_Mean - Bou Hanifia Mean Measurements; BMNH - British Museum of Natural History (now Natural History Museum, London) - Cremohipparion antelopinum; Crant - Cremohipparion antelopinum from the late Miocene of IndoPakistan (late Miocene age); EufeiL - Type Eurygnathohippus feibeli from Upper Nawata, Lothagam Hill, Kenya (ca. 6.0 Ma); EufeiMA Eurygnathohippus feibeli from Middle Awash, Ethiopia (ca. 6.0 Ma); EufeiS - Eurygnathohippus feibeli from Sahabi, Libya; Euhoo_MEAN - Eurygnathohippus hooijeri from Langebaanweg, South Africa (ca. 5.0 Ma); MMTT 13 - Hipparion campbelli, locality (MMTT13, 7.9 Ma; Bernor, 1986, 1986; Bernor et al. 2016); Pl_C_MEAN-Plesiohipparion sp. China (ca. 5 Ma.; Bernor et al. 2015b); SAM_MEAN - Eurygnathohippus hooijeri Type assemblage, Langebaanweg, South Africa (ca. 5 Ma.).

Museum collections-AMNH - American Museum of Natural History, New York (AMNH numbers); BMNH - Natural History Museum, London, England (BMNH numbers); MMTT National Museum of Iran, Tehran (MMTT numbers); MNHN - Museum National d'Histoire Naturelle, Paris (MNHN numbers); THP - Tianjin Museum of Natural History, Tianjin, China (THP numbers).

Systematic conventions - Anatomical descriptions have been adapted from Nickel et al. (1986). Getty (1982) was also consulted for morphological identification and comparison. Hipparion monographs by Gromova (1952) and Gabunia (1959) are cited after the French and English translations. The nomen Hipparion has been used in a variety of ways by different authors. We follow 
characterizations and definitions for hipparionine horses as most recently defined in Bernor et al. (2016) and Bernor and Sen (2017). We recognize the following lineages of Old World hipparionine horses: Cormohipparion, Hippotherium, Cremohipparion, Hipparion, "Sivalhippus", Eurygnathohippus (=senior synonym of "Stylohipparion"), Proboscidipparion and Plesiohipparion. These lineages have recently been reviewed by Qiu et al. (1987), Bernor (1985); Bernor and Harris (2003), Bernor and White (2009), Bernor et al. (1996, 2003, 2005, 2010, 2013, 2014, 2015a \& b), Wolf et al. (2013), Bernor \& Sun (2015), Bernor et al. (2016) and Bernor and Sen (2017). Bernor and Bernor et al. publications include measurements.

Metric procedures-Measurements are all given in millimeters and rounded to $0.1 \mathrm{~mm}$. Measurement numbers (M1, M2, M3, etc.) refer to those published by Eisenmann et al. (1988) and Bernor et al. (1997) for the skulls and postcrania. Tooth measurement numbers refer to those published by Bernor et al. (1997). Bernor and Armour-Chelu (1999), Bernor and Harris (2003), Bernor and Scott (2003), Bernor et al. (1990, 2003, 2004, 2005, 2010; 2013, 2015a \& b), Gilbert and Bernor (2008), Bernor and Haile Selassie (2009) and Bernor and White (2009) have compared African hipparions to an extensive series of Late Miocene-Pleistocene Eurasian and African assemblages. Bernor and Sun (2015) have recently reviewed cheek tooth ontological stages in Chinese Plesiohipparion and Proboscidipparion.

In various studies, Eisenmann (see Eisenmann 1995 for a comprehensive summary), has used $\log 10$ ratio diagrams to evaluate differences in hipparion metapodial proportions as a basis for recognizing taxa and their evolutionary relationships. Bernor et al. (2003) and Bernor and Harris (2003) have used multiple statistical tests, including univariate, bivariate and multivariate statistics as well as $\log 10$ ratio diagrams to evaluate and resolve the alpha systematics of hipparionine horses. Bernor et al. (2005) used $\log 10$ ratio diagrams together with multivariate statistics to evaluate metapodial and first phalangeal evidence for postcranial evolution in Ethiopian hipparions. Bernor et al. (2016) have used $\log 10$ ratios combined with bivariate plots to integrate postcranial with cranial morphology to characterize multiple species of Maragheh, Iran hipparions. We incorporate these 
previously used methodologies in this work. Our statistical analyses use the skeletal population from Höwenegg (Hegau, southern Germany, 10.3 Ma; Bernor et al. 1997) for calculating 95\% confidence ellipses used in bivariate plots, and $\log 10$ mean standard values for all $\log 10$ ratio diagrams (MCIIIs, MTIIIs and 1PHIIIs).

\section{Statistical Analysis}

Bivariate plots - Table 16.2 provides measurements of the Baynunah specimens used in this analysis. These measurements were taken by R.L. Bernor.

Höwenegg, Germany (10.3 Ma; Bernor et al. 1997 which includes population statistics on all skulls, mandibles, dentitions and bones) is used as the population standard for calculating $95 \%$ ellipses. In addition, we include the following hipparion samples in the analysis: Sahabi, Libya (symbol b; ca. 7.5-7.0 Ma., MN 12 and 13); Yushe and Nihowan, China specimens of Plesiohipparion (symbol c; 6-2.5 Ma.); Middle Awash and Gona, Ethiopia (symbol e; 6-1 Ma); Eppelsheim, Germany (symbol g; ca. 10.3-10.0 Ma); Pikermi, Greece (symbol i; ca. 8 Ma); Sinap (symbol n; ca 10.7-9.9 Ma); Siwalik Hills, Pakistan (symbol p; ca. 10.7 - 6.9 Ma); late Miocene - Pleistocene of Tanzania (symbol t; ca. 7-1 Ma); Perpignan, France (symbol w; ca. 4-3 Ma); late Miocene - Pliocene of Kenya (symbol k; ca. 8-2.5 Ma); Çalta, Turkey (symbol Z for Proboscidipparion heintzi and z for Plesiohipparion longipes; ca. $4 \mathrm{Ma}$ ).

Analyses of the Baynunah hipparions include bivariate plots of CALC, AST, MCIII, MTIII and 1PHIII. Analysis of dP2 was recently reported by Wolf and Bernor (2013) and Bernor et al. (2015). All of these skeletal elements are clearly differentiated with the exception of 1PHIII. While anterior and posterior 1PHIII can be clearly differentiated in living Equus, the same cannot be said for all hipparions. The Höwenegg Hippotherium primigenium skeletons were found in articulation and thus the anterior versus a posterior 1PHIII are known. However, the statistical differences between these phalanges are minor at best, which has led us to analyze all 1PHIII together. Some advanced African hipparions may in fact differ significantly in anterior versus posterior 1PHIII dimensions, but this has not been adequately demonstrated across individual lineages. Bivariate plots will include two 
parallel sets of plots when needed: one of our entire sample; a second of the Baynunah specimens with China, Akkasdagi (7.1 Ma, Turkey) and Calta (4.0 Ma, Turkey) alone to highlight their plotted points clearly.

Calcaneum maximum length (M1) versus distal maximum breadth is plotted in Figures 16.2A and 2B. Figure 2A plots the $95 \%$ ellipse of the Höwenegg hipparions with specimens from the Dinotheriensand (g), Tanzania (t), Pakistan (p), Pikermi (k), Calta (Z) falling within the ellipse. There are specimens from Ethiopia (e), Pakistan (p) and Tanzania (t) that are large and plot above the ellipse. Baynunah (D) calcaneum falls well below the Höwenegg ellipse with small specimens from Maragheh $(m)$, Pakistan (p), Sahabi (b), Tanzania (t) and Sinap (n) falling below the ellipse. Figure 2B clearly shows the Baynunah (D) hipparion below the ellipse, indicating its smaller size than the Höwenegg sample, and Calta $(Z)$. The calcaneum bivariates indicate that the Baynunah hipparion is smaller than most of the Höwenegg sample.

\section{FIGURES 16.2, 16.3 and 16.4 NEAR HERE. EACH ONE COLUMN WIDTH}

Figures 16.3A and B plot maximum length (M1) versus distal articular (M5) of astragalus. Astragali are durable in the fossil record and are well represented in our sample with a scatter mostly along the Höwenegg 95\% ellipse axis with larger specimens from Ethiopia (e), Tanzania (t), Pakistan (p) and Calta ( $\mathrm{z}$ and $\mathrm{Z}$ ) prevalent (Fig. 3A). Figure 3B plots one Baynunah astragalus at the bottom of the Höwenegg ellipse and two below the ellipse (D). There are a total of 7 astragali from Calta ( $\mathrm{z}$ and Z) at the top, or above the Höwenegg ellipse. Distinguishing "Plesiohipparion" cf. longipes from Proboscidipparion heintzi astragali is difficult to ascertain, so these assignments can only be considered estimates of affinity (re: Eisenmann and Sondaar, 1998; Bernor and Sen, 2017). The astragalus bivariates indicate that the Baynunah hipparion is smaller than most of the Höwenegg sample. Although we cannot be certain that these astragali belong to adult individuals (and have therefore attained their maximum size), size findings are congruent with comparisons using other elements. Figure 16.4A plots MCIII maximum length (M1) versus maximum distal articular width 
(M11) of a large sample of hipparions in comparison to the Höwenegg ellipse. Ethiopia (e), China (C) have specimens above the Höwenegg 95\% ellipse. Akkasdagi (a) and Baynunah (D) have long and slender specimens above and to the left of the ellipse, whereas Maragheh (m), Pikermi (k) have several specimens to the left of the ellipse, being more slender than the Höwenegg sample. Maragheh (m), Pakistan (p), Sinap (n), Pikermi (k), Tanzania (t) all have specimens that plot within the Höwenegg ellipse. Maragheh (m), Sinap (n) and Perpignan (w) have small specimens that plot below the ellipse. MCIIIs with wide distal articular widths (M11) include specimens from Tanzania (t), Pakistan (p), Perpignan (w; short and wide) and Calta Proboscidipparion heintzi. Figure 16.4B clearly plots the Baynunah MCIII M1 vs. M11 in a cluster of Akkasdagi (a) “Plesiohipparion” cf. longipes being nearly as long as China Plesiohipparion houfenense. Proboscidipparion heintzi (Z) plots to the right of the Höwenegg ellipse being relatively short (M1) and wide (M11). Figure 4C plots MCIII distal articular width (M11) versus midsagittal keel diameter (M12) and shows that Baynunah plots just inside the left border of the Höwenegg ellipse and another specimen just outside the lower border of the Höwenegg ellipse. Figure 16.4D plots MTIII distal articular width (M11) versus midsaggital keel diameter (M12) and plots two Baynunah hipparions just below the Höwenegg ellipse. These fragmentary MPIII specimens overlap in their dimensions but also are incrementally smaller than the Akkasdagi hipparion and overlap and are smaller than the Höwenegg sample. There is no reason to consider any of these specimens as belonging to two different sized hipparions and therefore we refer them to "Hipparion" abudhabiense.

\section{FIGURES 16.5 and 16.6 NEAR HERE. EACH ONE COLUMN WIDTH}

AUH 1797 is a badly weathered MTIII collected by the Whybrow-Hill expedition in 1998 but not described by Whybrow and Eisenmann (1999). At the time of writing it is still in the Natural History Museum of London. We have no measurements on this specimen and can only say herein that it is elongate and slender with fragmentary proximal and distal ends.

Figures 16.5A and B plot maximum length (M1) versus proximal articular width (M4) of 1PHIII. As 
with our other samples of bones cited above, there are several specimens larger than the Höwenegg ellipse from Ethiopia (e; the largest of our sample), Calta ( $\mathrm{z}$ and Z), Pakistan (p), Tanzania ( $\mathrm{t}$ ) and Pikermi (k). There is a dense cluster of specimens within the Höwenegg ellipse (m, t, p, Z), to the right of the ellipse (Z, p, k, e), to the left of the ellipse (m, p, g) and below the ellipse (m, n, k, g). Figure 5B plots Calta Proboscidipparion heintzi $(\mathrm{Z})$ is in the upper right corner, outside and above the Höwenegg ellipse while the Baynunah hipparions (D) plot on the left side and outside to the left of the Höwenegg ellipse.

Figure 16.6 (A-D) provides a series of $\log 10$ ratio plots of MCIII, with the mean of the Höwenegg sample used as the standard. Figure 6A plots Hadar Eurygnathohippus hasumense (AL155$6 \mathrm{BB})$ as larger and more robust than the rest of the sample for all specimens. The $\log 10$ ratios for the rest of the sample from Langebaanweg (SAM_MEAN), Bou Hanifia (BH_MEAN), Lothagam (EufeiL) and Sahabi (EufeiS) Eu. feibeli are very similar: they have strongly contrasting length (M1) versus midshaft width (M3) and distal articular (M11) and supraarticular (M10) measurements. There is a very strong contrast in midshaft width (M3) versus midshaft depth (M4) which is believed reflect cursorial behavior (Bernor et al. 2003). The Bou Hanifia “Cormohipparion" africanum is believed to represent the primitive morphotype for Old World hipparions (Bernor and White, 2009). Figure 6B more dramatically exhibits the close identity of Bou Hanifia (BH_MEAN), Lothagam (EufeiL) and Sahabi (EufeiS) Eu. feibeli and Siwalik Cremohipparion antelopinum (Crant) in their log10 ratios with lengthening (M1), narrow midshaft width (M3) versus relatively great midshaft depth (M4) being particularly dramatic.

Bou Hanifia is primitive in its modest length. Figure 16.6C shows the substantially greater lengthening of the Baynunah MC III (AUH 1499) compared to Bou Hanifia (BH_MEAN), Eurygnathohippus feibeli (EufeiL and EufeiS) and Cremohipparion antelopinum as directly reflected in the bivariate plots. Figure 16.6D demonstrates the strong lengthening of China Plesiohipparion houfenense (P1_C), Baynunah (AUH 1499) and Akkasdagi (AK_MEAN). This plot supports an attribution of the Akkasdagi and Baynunah hipparion to "Plesiohipparion" cf. longipes and their close relationship to the larger latest Miocene - early Pliocene Chinese species Plesiohipparion houfenense. 
FIGURE 16.7 NEAR HERE. ONE COLUMN WIDTH

Figures 16.7A-C provide a $\log 10$ plot of a sample of 1PHIII's. Figure 16.7A plots the two AL155 (Hadar, Ethiopia) specimens and demonstrates that they are the largest and most robust 1PHIIIs of our sample, particularly for measurements M3-9. The two populations of Eurygnathohippus feibeli from Lothagam Upper Nawata and Sahabi (EufeiL and EufeiS) are virtually identical in their dimensions, Lothagam being slightly longer. Langebaanweg Eurygnathohippus hooijeri has a similar $\log 10$ trajectory, but is larger than Eufei. Figure 7B shows that Cremohipparion antelopinum (3 BMNH numbers) are all the longest of our entire sample. Maragheh Hipparion campbelli (2 MMTT numbers) plot very closely with African EufeiL and EufeiS. Figure 16.7C shows that all plots, EufeiMA, EufeiL, EufeiS, Hipparion campbelli (2 MMTT numbers and 3 Baynunah specimens) all plot very close to one another having a length (M1 and M2) very close to the Höwenegg sample, but with Eufei plotting lower in width (M3 and M4) and distal supraarticular width (M6): they are relatively slender 1PHIIIs.

\section{Systematic Paleontology}

Order PERISSODACTYLA Owen, 1848

Suborder HIPPOMORPHA Wood, 1937

Family EQUIDAE Gray, 1821

Tribe HIPPARIONINI Quinn, 1955

"Hipparion” abudhabiense Eisenmann and Whybrow, 1999

Etymology—Named for the Emirate of Abu Dhabi, United Arab Emirates.

Holotype-AUH 270, right mandibular fragment (Eisenmann and Whybrow, 1999; Fig. 1a 
\& 1b; Fig. 9A and B herein).

Hypodigm-See Table 16.1.

Type locality_Jebel Dhanna, site JDH 3, Al Dhafra Region (formerly Al Gharbia, Baynunah, or Western Region) of the Emirate of Abu Dhabi, United Arab Emirates.

Age-Late Miocene, ca. $7 \mathrm{Ma}$

Geographic distribution-Abu Dhabi. Possibly related to 7.1 Ma "Plesiohipparion" cf. longipes from Akkasdagi, Turkey and Chinese Plesiohipparion houfenense.

TABLE 16.1 NEAR HERE.

Diagnosis-(modified from Eisenmann and Whybrow, 1999) Skull unknown. Size medium; lower cheek tooth series about $140 \mathrm{~mm}$. long; mandibular corpus deep; symphysis broad and relatively short; premolar and molar row of similar length; cheek teeth hypsodont, 60-65 mm maximum height; metaconid usually rounded, metastylid usually squared with some incidence of lingual pointing; ectoflexids deep on molars and variably deep on premolars; no ectostylids apparent on any adult cheek teeth; protostylids variable being an open loop or closed elliptical-shaped ring. In maxillary cheek teeth, protocones varying from being elongate and lingually flattened in early wear, becoming small and rounded later in wear; plications and pli caballins moderately developed being most complex on the opposing borders of the pre- and postfossettes. Podials are medium size, plotting slightly below the Höwenegg 95\% ellipse in most cases. Metacarpal III is extremely elongate.

FIGURE 16.8 NEAR HERE. 1.5 COLUMN WIDTH

Description - The hypodigm for Baynunah "Hipparion" abudhabiense is listed in Table 1, herein. We select representative specimens of the maxillary cheek teeth, mandibles and mandibular dentition and postcranial elements that were analyzed herein for description and figuring. Maxillary cheek teeth rendered here are AUH 644, rt. P2 (Fig. 16.8A, labial and 16.8B, occlusal), 
AUH 1264, 1t. M1 or 2 (Fig. 16.8C, labial) and AUH 676, rt. M1 (Fig. 16.8D, occlusal). AUH 644 is in advanced wear, having a mesostyle height (M5) of $18.2 \mathrm{~mm}$. and exhibits the following salient features of its occlusal pattern: anterostyle elongate, despite its advanced wear; prefossette's distal border is relatively complex given its advanced wear, postfossette's mesial border is more complex than its distal border, distal border of prefossette linked with mesial border of postfossette (a primitive feature, Bernor et al. 2017); pli caballin is double despite its advanced wear; hypoglyph is shallowly incised. AUH 1264 is a left M1 or 2 with a crown height of $45.7 \mathrm{~mm}$. (M5), preserving most of the labial surface of the crown. It is slanted distalward, with the mesiolabial cusp (paracone) being elevated to a level flush with the mesostyle giving it a high/low borderline height and rounded shape indicative of mixed feeding/grazing mesowear signature. AUH 676 is a right M1 with a crown height of $59.7 \mathrm{~mm}$. This tooth is in an early stage of wear with pre- and postfossettes not yet expressing plications, mesostyle is narrow and pointed labially, protocone is elongate and flattened lingually; hypoglyph is very deeply incised; occlusal morphology reflects the early stage-of-wear of this juvenile individual. This cheek tooth suggests that the maximum crown height of "Hipparion" abudhabiense was $60-65 \mathrm{~mm}$.

AUH 270 (Figs. 16.9A, labial and 16.9B, occlusal) is the type specimen of " $H$ ".

abudhabiense (Eisenmann and Whybrow, 1999 their fig. 19.3; Fig. 16.9A\&B herein). The specimen is maintained at the Natural History Museum, London and we have depended on Eisenmann and Whybrow's (1999) description and images (secured by MB and FB) for our description herein. Bernor saw this specimen personally in Abu Dhabi during the March, 1995 conference held at Jebel AlDhanna, UAE but was unable to access it at the Natural History Museum, London.

\section{FIGURE 16.9 NEAR HERE. 1.5 COLUMN WIDTH}

In lateral view, the mandible preserves p2-m3, is lacking the symphysis, has its ventral margin broken but preserves the base of the ascending ramus and a portion of the ramus posterior to $\mathrm{m} 3$. Eisenmann and Whybrow (1999, their tab. 19.1) report that p2-p4 are $72 \mathrm{~mm}$. long and $\mathrm{m} 1-\mathrm{m} 3$ is 70 
$\mathrm{mm}$. No measurement for $\mathrm{p} 2-\mathrm{m} 3$ is given, but the premolar and molar length measurements support their claim of a total tooth row dimension (worn individual) of about $140 \mathrm{~mm}$. We estimate that a middle stage-of-wear individual would have had a total cheek tooth row dimension of about $145 \mathrm{~mm}$. The individual cheek teeth have the following salient features: $\mathrm{p} 2$ has a shortened anterostylid due to advanced wear, metaconid is round, metastylid is square, preflexid is short with simple margins, postflexid more elongate and also with simple margins, linguaflexid V-shaped, ectoflexid deep extending to pre-postflexid; $\mathrm{p} 3$ has metaconid rounded, metastylid square, preflexid with mild plication, postflexid elongate and simple, linguaflexid U-shaped, ectoflexid not as deeply incised as in p2; p4 with metaconid and metastylid as in p3, linguaflexid has a deep U-shape, ectoflexid is very deeply incised separating metaconid-metastylid (primitive feature), preflexid as in $\mathrm{p} 3$, postflexid as in p2; m1 with a prominent, open loop- shaped protostylid, a lingually pointed metaconid, and squared metastylid, linguaflexid is a deep U-shape, pre- and postflexids have simple margins, ectoflexid is very deeply incised uniting with the linguaflexid lingually; $\mathrm{m} 2$ has protostylid as in $\mathrm{m} 1$, a rounded metaconid and pointed metastylid, linguaflexid is U-shaped, pre- and postfossettes and ectoflexid as in $\mathrm{m} 1 ; \mathrm{m} 3$ is fractured between metaconid and metastylid, has metaconid rounded, metastylid is damaged, pre- and postfossettes as in other molars, talonid has a prominent entoconid and typical hypoconulid.

AUH 1284 is a mandible with complete symphysis, incisor roots suggesting that they were horizontally aligned, fragmentary p2-m3 and base of the mandibular ramus (Fig. 16.9C, labial, 16.9D, occlusal). The occlusal view reveals a relatively broad and short symphysis lacking incisors and canine teeth, cheek tooth crowns are broken on the left series, preserving limited occlusal features on right $\mathrm{p} 2$ and $\mathrm{p} 3$, but obscured features on $\mathrm{p} 4-\mathrm{m} 3$. The right cheek tooth series is clearly worn. The $\mathrm{p} 2$ has a broken anterostylid, metaconid is rounded, metastylid square shape, pre- and postflexid shortened with simple margins due to wear, linguaflexid a shallow U-shape, ectoflexid is short. The p3 has rounded metaconid and metastylid, pre- and postflexid as in p2, linguaflexid a medium depth Vshape and ectoflexid of moderate depth, not separating pre- and postflexid. The canine's base is large suggesting that this was a male individual. The significance of this specimen is that it preserves a 
moderate-to-short symphysis with a relatively broad incisor region that apparently had horizontally aligned incisors.

An additional mandible of a senile individual, AUH 452 was described and figured by Eisenmann and Whybrow (1999: their fig. 5a and b). This mandible has a short symphysis with incisor alveoli retained, a partial mandibular ramus and p2-m1. The cheek teeth are extremely worn, especially the p2 and p3 and preserve no occlusal details. A fourth mandible is known, AUH 1146, that is still encased in its plaster jacket and highly fragmented. This specimen is in need of extensive preparation and cannot be safely studied at this time.

FIGURE 16.10 NEAR HERE. 1.5 COLUMN WIDTH

In addition to the mandibles we describe and illustrate three lower cheek teeth (Fig. 16.10 AF): AUH 1712, a right p4 (A, B), AUH 1535, a left $\mathrm{m} 1$ (C, D) and AUH 1560, a right m2 (E, F). AUH 1712 has straight, vertical walls typical of a p4. Figure 16.10A illustrates the labial wall and distally the serial sampling of enamel for isotopic analysis. The specimen is worn with a crown height of 54.6 $\mathrm{mm}$. The occlusal surfaced (Fig. 16.10B) reveals that this specimen is past early wear and would have likely had a crown height greater than $60 \mathrm{~mm}$. Salient occlusal features of AUH 1712 include: protostylid a closed elliptical-shaped structure; metaconid rounded, metastylid square-shape; linguaflexid a moderately deep V-shape; preflexid with slight plication on labial margin; postflexid elongate, plicated on its labial margin, extending into isthmus between metaconid and metastylid; ectoflexid moderately deep extending between pre- and postflexid. AUH 1535 has a crown height of $46.8 \mathrm{~mm}$, is likewise serially sampled (Fig. 16.10C) on its mesio-labial surface. Its salient morphological features (Fig. 16.10D) include: metaconid rounded, metastylid squared with disto-labial pointing; linguaflexid has a broad U shape; preflexid with complexity on its mesial border, postflexid with simple margins; ectoflexid deeply incised invading isthmus between pre- and postflexid. AUH1560 (Fig. 16.10E-F) is worn, has wind damaged enamel and a crown height of $30.2 \mathrm{~mm}$. Despite the wind damaged erosion, the following salient features are clear: protostylid is a long, 
mesially open loop extending distalward on the labial surface; metaconid and metastylid are pointed lingually; pre- and postflexids have simple margins; linguaflexid is V-shaped; ectoflexid is deep penetrating the metaconid-metastylid isthmus. None of the cheek teeth we have studied and illustrated herein exhibit an ectostylid. However, some of the lower cheek teeth have exhibited lingually pointed metaconids and metastylids.

FIGURES 16.11, 16.12, 16.13, 16.4 NEAR HERE. EACH ONE COLUMN WIDTH

Remarks - We have undertaken a statistical comparison of the Baynunah and relevant Eurasian and African hipparions using bivariate variables. MCIII and 1PHIII have, in addition, been analyzed using $\log 10$ ratio diagrams with the Höwenegg population sample being used as the mean $\log 10$ standard. The calcaneum, AUH 1609 (Fig. 16.11A and B) has been shown to be slightly smaller than the Höwenegg sample (re: Figs. 2A and 2B) which is a congruent result with mandibular cheek tooth series size. We figure a single right astragalus attributable to "Hipparion" abudhabiense, AUH 340 (Fig. 16.12A and B). Bivariate comparisons show that the Baynunah astragalus sample is again smaller than most of the Höwenegg sample (Fig. 16.3A and B) and congruent with the calcaneum and mandibular metrics. AUH 1792, left MCIII (Fig. 16.13), is fragmentary but preserves enough morphology for bivariate (Fig. 16.4A and B) and $\log 10$ ratio (Fig. 16.6A-D) analyses. The Baynunah MCIII compares very closely with Akkasdagi (Koufos and Vlachou, 2005; Turkey, 7.1 Ma) “Plesiohipparion” cf. longipes (Eisenmann and Sondaar, 1998; Bernor and Sen, 2017). Bivariate plots of MCIII and MTIII distal dimensions M12 vs. M11 show that there is not any significant size diversity in the Baynunah MPIII sample: all MPIIIs are referable to "Hipparion" abudhabiense. The $\log 10$ plots, in particular Figures 6C and D support a "best fit" attribution to "Plesiohipparion" cf. longipes closely similar to the Akkasdagi form, and, somewhat more distantly China Plesiohipparion houfenense (Qiu et al. 1987; Bernor and Sun, 2015; Bernor and Sen, in 2017). The 1PHIII, AUH 324 (Fig. 16.14A and B) as well as AUH 1279 and AUH 165 was found to be more slender than the Höwenegg sample (Fig. 16.5A and B) while Figures 
16.7A-C shows that the Baynunah specimens are, as is Eurygnathohippus feibeli (Middle Awash, Lothagam and Sahabi) and Maragheh Hipparion campbelli, elongate and slender. These similarities are likely due to convergence evolution of elongate-slender 1PHIIIs. Eisenmann and Whybrow (1999) documented the presence of a second, larger species of hipparion at Baynunah. However, all the specimens they attributed that we were able to examine are, in our opinion, not significantly larger than material of "H." abudhabiense.

\section{“Hipparion” small sp.}

Description-Eisenmann and Whybrow (1999) noted that there is a second, smaller species of hipparion at Baynunah. Tables 1 and 2 have recognized three smaller specimens in the sample: AUH 1695, 1t. astragalus; AUH 261, 1t. p4; AUH 397b, rt. M3. We believe that these specimens are too small to be referred to "Hipparion" abudhabiense. AUH 397b (Fig. 16.15A and B) is a rt. M3 in early wear. This tooth is small, has a crown height of only $38.1 \mathrm{~mm}$, simply plicated pre- and postfossettes, pointed mesostyle, protocone triangular-shape and flattened lingually. This specimen is too small and too low crowned to be referred to "Hipparion" abudhabiense. AUH 1695 (Fig. 16.16A and B) is a small right astragalus. Juvenile astragali are notoriously difficult to differentiate from adult astragali and generally are smaller than adults. We cannot be certain that this specimen is referable to "Hipparion" small sp. AUH 261 is a left small p4 which might also be referable to "Hipparion" sp. sm(all) with a crown height of $54.3 \mathrm{~mm}$ (Fig. 16.17).

FIGURES 16.15, 16.16, 16.17 NEAR HERE. EACH ONE COLUMN WIDTH.

Remarks - Small hipparions are common in late Miocene Western Eurasian faunas. Bernor et al. (2016) undertook a comprehensive analysis of Maragheh hipparions and found that the small hipparion, Cremohipparion matthewi, was likely related to the somewhat larger form, Cremohipparion moldavicum. Likewise, the late Miocene Greek fauna of Samos has a multiple small taxa incuding 
Cremohipparion matthewi and Cremohipparion nikosi (Bernor et al. 1996; Vlachou and Koufos 2009; Bernor et al. 2016). AUH 261 and AUH 397b are quite possibly related to the Cremohipparion matthewi-nikosi group. Its correlation at 7.1 Ma. is roughly congruent with the Samos Q5 hipparions.

\section{Discussion}

Eisenmann and Whybrow (1999) established the taxon Hipparion abudhabiense based on a fragmentary mandible, AUH 270 . They claimed that the type specimen's symphysis was diagnostic and argued for an evolutionary relationship to Greek Hipparion dietrichi. "Hipparion" abudhabiense was diagnosed as being medium-to small in size and that there was a second larger species "Hipparion" sp. diagnosed as being "medium-large" in size. The current sample under consideration is considerably larger in number of specimens, has additional mandibular, cheek tooth and particularly important postcranial material. The complete, albeit fractured MCIII (AUH 1499), calcaneum (AUH 1609) and multiple astragali (Tables 16.1 and 16.2) offer new insights on the taxonomy of the Baynunah hipparions. "Hipparion" abudhabiense is a medium sized hipparion, slightly smaller than the Höwenegg population (based on 95\% ellipse and $\log 10$ ratios) with extremely elongate MCIIIs comparing closely in maximum length (M1) versus distal articular width (M11) with Akkasdagi, Turkey (MN12, 7.1 Ma; Koufos and Vlachou, 2005) and Calta (MN14, ca. 4.0 Ma; Bernor and Sen, in 2017) "Plesiohipparion" cf. longipes, and by extension, Northern Kazakhstan "Plesiohipparion" longipes (MN13, ca. 7 Ma.). Our analysis of Baynunah fragmentary distal MPIIIs consistently show that they are of similar size and smaller than the Höwenegg sample. Akkasdagi and Calta "Plesiohipparion" cf. longipes appears to be related to China latest Miocene - Pliocene Plesiohipparion houfenense and early Pleistocene Chinese Plesiohipparion shanxiense (Bernor et al. 2015b; Nihowan, ca. 2.0 Ma). As far as currently known, Baynunah "Hipparion" abudhabiense exhibits an MPIII morphology most similar to Akkasdagi and Calta "Plesiohipparion" cf. longipes.

We do not insist that our referral of Baynunah "Hipparion" abudhabiense to "Plesiohipparion" cf. longipes is absolutely certain. While the Baynunah MCIII M1 vs M11 dimensions plot within the Akkasdagi cluster, and close to Chinese Plesiohipparion houfenense it 
must be noted that slenderization and lengthening of metapodial IIIs is a common theme in several Eurasian and African hipparion lineages (Bernor et al. 2003; Scott and Maga, 2005). Bernor et al. (2016) integrated crania, maxillary dentitions and metapodial III's from Maragheh and we hasten to add that even the most elongate and slender limbed forms Cremohipparion moldavicum and Hipparion campbelli did not achieve MCIII lengthening equivalent to "Plesiohipparion" longipes. Samos (Vlachou and Koufos, 2009) has a number of species with elongate- slender limbs including Hipparion dietrichi, the sister-taxon of Hipparion campbelli, the larger form Cremohipparion proboscideum, and smaller forms Cremohipparion "matthewi" and Cremohipparion nikosi. Integrating skull, dentition and postcranial data from Samos would be a very challenging undertaking and has, to date, not been achieved due to the complex species diversity of the equid fauna. The best chance for doing this rests with the AMNH Samos collection that has well provenanced and radioisotopically dated (Koufos et al. 2011) quarry samples. The Siwaliks also have the rare occurrence of a Cremohipparion, Cr. antelopinum known from the ca. 8 m.y. levels (Wolf et al. 2013).

Our analysis suggests that there are two species of hipparion from the Baynunah Formation. The dominant form is a medium sized species that has been referred to "Hipparion" abudhabiense with a "best fit" affinity to Akkasdagi and Calta "Plesiohipparion" cf. longipes based on the MCIII, AUH 1499. The MPIII lengthening of Abu Dhabi AUH 1499 is similar to Plesiohipparion houfenense (China), “Plesiohipparion” longipes (Pavlodar, Kazakhstan), or “Plesiohipparion” cf. longipes (Akkasdagi [7.1 Ma.] and Calta [4.0], Turkey; Bernor and Sen, 2017), and none of these taxa have ectostylids present on the lower cheek teeth. Bernor and Sun (2015) found that Asian Plesiohipparion and African Eurygnathohippus are sister taxa and Bernor et al. (2017) have found that ectostylids on the permanent cheek teeth occur in the oldest Eurasian hipparions from the Pannonian C of Central Europe, asserting that the presence of ectostylids is a primitive character for Old World hipparions. Only African Eurygnathohippus retained ectostylids and evolved them further in height, length and width (Bernor et al. 2010). The second smaller taxon is rare in the Baynunah Fm. and is a dwarf form that may well be related to the Eastern Mediterranean-Southwest Asian Cremohipparion matthewinikosi group (Bernor et al. 1996; Bernor et al. 2016). Given these observations, the Baynunah Fm. 
hipparions show an affinity with the late Miocene of Greece, Turkey, Iran, Kazakhstan and China. The possibility of their being directly related to eastern African Eurygnathohippus has not been demonstrated by the existing Baynunah equid material.

Demographically, of the almost 2000 catalogued specimens from the Baynunah Formation, Equidae are the most abundant mammalian family (10\%), followed by Bovidae (7\%) and Hippopotamidae (6\%). Kingston (1999) and Uno and Bibi (this volume) reported stable carbon isotopic values from equid tooth enamel ranging from about -8 to $+2 \%$, indicating mixed feeding (browse and grass). Taphonomically, vertebrate fossils are found within a fluviatile context whereby they were transported to their final deposition (e.g. Andrews 1999).

\section{Conclusions}

There are two species of "Hipparion" sensu lato found within the Baynunah Formation, UAE. The dominant form is a medium-sized hipparion originally referred to by Eisenmann and Whybrow (1999) to Hipparion abudhabiense. These authors suggested that there was a close resemblance to Greek late Miocene species Hipparion dietrichi based on its size and short mandibular symphysis. Based on about twice the sample size, with augmentation of complete postcranial bones, and in particular a complete, albeit fractured metacarpal III we find that the Abu Dhabi hipparion exhibits its closest resemblance to Turkish (Akkasdagi, 7.1 Ma. and Calta, 4.0 Ma) "Plesiohipparion” cf. longipes and Northern Kazakstan “Plesiohipparion” longipes.

"Hipparion" abudhabiense is the dominant hipparion in the Baynunah Formation. We have characterized this species as being medium size, smaller than the Höwenegg (Hegau, Germany, 10.3 Ma; Bernor et al. 1997) hipparion. The skull is unknown which makes it difficult to compare to the different lineages of hipparion. Cheek teeth show variability characteristic of hipparion taxa. Maxillary cheek teeth have protocones that vary from elongate and lingually flattened in early wear (AUH 676, rt. M1) to rounded later in wear (AUH 644, rt. P2); pre- and postfossettes that are moderately complex; mesostyle may have knife-like and pointed labially (AUH 644). Mandibular cheek teeth usually have rounded metaconid and squared metastylid but exhibits a labially pointed 
morphology in AUH 1560 (rt. m2). Ectoflexid occasionally exhibits the primitive character of being deep on the premolar teeth (AUH 270 and AUH 1560). Mandibles have short, broad symphyses. The second smaller species is only indicated based on a few specimens that seem too small to be " $H . "$ abudhabiense and their similarity to the Cremohipparion matthewi-nikosi clade.

Biogeographically, we favor "Hipparion" abudhabiense's relationship to Kazakhstan “Plesiohipparion” longipes and Turkish "Plesiohipparion” cf. longipes, and more distantly, Chinese Plesiohipparion houfenense. We reiterate Bernor and Sun (2015) and Bernor and Sen's (2017) belief that Plesiohipparion is the sister taxon of African Eurygnathohippus. We cannot, however absolutely rule out "Hipparion" abudhabiense's relationship to Greek Hipparion dietrichi nor Greek, Iranian and Siwalik Cremohipparion. It is likely that the rare, smaller hipparion is similar to the Cremohipparion matthewi - nikosi clade known from Greece, Iran and Libya (Bernor et al. under current study). Our estimation of the age of the Baynunah Fm., based on its hipparion fauna is ca. 7 Ma. As such, it is correlative with the Pavlodar, Kazakhstan, the Siwalik Dhok Pathan Formation, Akkasdagi, Turkey, the upper levels of Samos, Greece and Sahabi, Libya.

\section{Acknowledgments}

We dedicate this manuscript to the memory of Peter Whybrow and Andrew Hill who initiated their collaborative project in 1986 . We further acknowledge the hours, days, weeks and years of laborious prospecting and excavations by all that worked in the Baynunah Formation collecting its vertebrate fauna. Every fragment, partial and whole bone and tooth was hard fought-for bringing together the current record of this fauna. Enough equid material has been accumulated over 30 years to allow us a window into its record. Bernor wishes to acknowledge funding support from the following research grants: EAR0125009, 1113175, 1138908, and 1558586 for the study of fossil horses and NSF:DBI:ABI Innovation 1759882 FuTRES. This is FuTRES publication number 18 (www.futres.org). Bibi was supported by a National Science Foundation (NSF) Graduate Research Fellowship, an NSF International Research Fellowship, a Leibniz-DAAD Fellowship, and a Gerstner Scholarship. Additional support has come to Bernor and Bibi from the Revealing Hominid Origins 
Initiative (NSF-HOMINID, PIs T. White and F. C. Howell).

\section{References}

Andrews P. (1999) Taphonomy of the Shuwaihat proboscidean, late Miocene, Emirate of Abu Dhabi, United Arab Emirates. In: Whybrow P. J. Hill A. P. (ed) Fossil Vertebrates of Arabia, with Emphasis on the Late Miocene Faunas, Geology, and Palaeoenvironments of the Emirate of Abu Dhabi, United Arab Emirates, Yale University Press, New Haven, p 338-353

Armour-Chelu, M. and R. L. Bernor. (2011). Equidae, In T. Harrison (ed.) Geology and Paleontology of Laetoli, Springer-Verlag: New York.:295-326.

Beech M., Kraatz B., \& Bibi F. (this volume). The History of Paleontological Investigation in Western Abu Dhabi Emirate. In F. Bibi, B. Kraatz, M. Beech, \& A. Hill (eds.) Sands of Time: Late Miocene Fossils from the Baynunah Formation, U.A.E. (pp. xxx). Cham: Springer.

Bernor, R.L. (1985). Systematics and Evolutionary Relationships of the Hipparionine Horses from Maragheh, Iran. Paleovertebrata, 15(4): 173-269.

Bernor, R.L. (1986). Mammalian Biostratigraphy, Geochronology and Zoogeographic Relationships of the Late Miocene Maragheh Fauna, Iran. Journal of Vertebrate Paleontology, 6 (1): 76-91.

Bernor, R.L. \& Armour-Chelu, M. (1999). Toward an Evolutionary History of African Hipparionine Horses. In Brommage, T. \& Schrenk, F. (eds) African Biogeography, Climate Change and Early Hominid Evolution, Oxford University Press, New York: 189-215.

Bernor, R.L., Armour-Chelu, M., Gilbert, H., Kaiser, T. \& Schulz, E. (2010). Equidae., In Werdelin, L. \& Sanders, B. (eds) Cenozoic Mammals of Africa, University of California Press, Berkeley: 685-721.

Bernor, R.L., Ataabadi, M. M., Meshida, K. \& Wolf. D. (2016). The Maragheh Hipparions; Late Miocene of Azerbaijan, Iran. Palaeobiology and Palaeodiversity, 96: 453-488.

Bernor, R.L., N. T. Boaz and L. Rook. (2012). Eurygnathohippus feibeli (Perissodactyla: Mammalia) from the late Miocene of Sahabi (Libya) and its evolutionary and Biogeographic Significance. Bolletino della Societa Paleontologica Italiana,. 51(1): 39-48. 
Bernor, R.L., Coillot, T. \& Wolf, D. (2014). Phylogenetic Signatures in the Juvenile Skull and Dentition of Olduvai Gorge Eurygnathohippus cornelianus (Mammalia: Equidae). Revista Italiana di Paleontologia e Stratigraphia, 120(2): 243-252.

Bernor, R.L., Gilbert, H., Semprebon, G., Simpson, S. \& Semaw, S. (2013). Eurygnathohippus woldegabrieli sp. nov. (Perissodactyla: Mammalia) from the Middle Pliocene of Aramis, Ethiopia (4.4 Ma.). Journal of Vertebrate Paleontology, 33(6):1472-1485.

Bernor, R.L., U. Goehlic, M. Harzhauser and G. Semprebon (2017). Stratigraphy, Chronology, Systematics and Paleoecology of the Vienna Basin Pannonian C Hipparions (basal MN9, late Miocene). Palaeoclimatology, Palaeogeography and Palaeoecology.

Bernor, R.L. \& Haile Selassie, Y. (2009). Equidae. In Haile-Selassie, Y. \& Woldegabriel, G. (eds), Ardipithecus kadabba: Late Miocene Evidence from the Middle Awash, Ethiopia, University of California Press, Berkeley: 397-428.

Bernor, R.L. \& Harris, J. (2003). Systematics and Evolutionary Biology of the Late Miocene and Early Pliocene Hipparionine Horses from Lothagam, Kenya. In Leakey, M. \& Harris, J. (eds), Lothagam: The Dawn of Humanity in Eastern Africa.. Columbia University Press, New York: $387-438$.

Bernor, R.L., Harzhauser, M., Goehlich, U. \& Semprebon, G. (2017). The Pannonian C Hipparions from the Vienna Basin. Palaeogeography, Palaeoclimatology, Palaeoecology, 476 (2017): 2841.

Bernor R.L., Kaiser, T.M. \& Nelson, S.V. (2004). The oldest Ethiopian hipparion (Equinae, Perissodactyla) from Chorora: Systematics, paleodiet and paleoclimate. Courier Forschunginstitut Senckenberg, 246: 213-226.

Bernor, R.L., Koufos, G.D., Woodbune, M.O. \& Fortelius, M. (1996). The Evolutionary History and Biochronology of European and Southwest Asian Late Miocene and Pliocene Hipparionine horses. In Bernor, R.L., Fahlbusch, V. \& Mittmann. H.-W. (eds), The Evolution of Western Eurasian Neogene Mammal Faunas; Columbia University Press, New York: 307-338.

Bernor, R.L., Meshida, K. \& Sun, B. (2015a). Phylogenetic Signatures in the Juvenile Skulls and 
Cheek Teeth of Pleistocene Proboscidipparion sinense, China. Revista Italiana di Paleontologia e Stratigraphia, 121(2): 255-264.

Bernor R.L., Qiu Z, \& Hayek L. (1990). Systematic revision of Chinese hipparion species described by Sefve, 1927. American Museum Novitates, 2984: 1-60.

Bernor, R.L. \& Scott, R.S. (2003). New Interpretations of the Systematics, Biogeography and Paleoecology of the Sahabi Hipparions (latest Miocene), Libya. Geodiversitas, 25(2): 297319.

Bernor, R.L., Scott, R.S., Fortelius, M., Kappelman, J. \& Sen, S. (2003). Systematics and Evolution of the Late Miocene Hipparions from Sinap, Turkey. In Fortelius, M., Kappelman, J., Sen, S. \& Bernor, R.L. (eds). The Geology and Paleontology of the Miocene Sinap Formation, Turkey. Columbia University Press: New York: 220-281.

Bernor, R.L., R.S. Scott \& Y. Haile-Selassie. (2005). A Contribution to the Evolutionary History of Ethiopian Hipparionine Horses: Morphometric Evidence from the Postcranial Skeleton. Geodiversitas, 27(1): 133-158.

Bernor, R.L. \& Sen, S. (2017). Proboscidipparion and Plesiohipparion from the early Pliocene of Calta, Turkey. Geodiversitas, 39(2): 1-30.

Bernor, R.L. \& B. Sun. (2015). Morphology through ontogeny of Chinese Proboscidipparion and Plesiohipparion and observations on their Eurasian and African Relatives. Vertebrata PalAsiatica, 53(1):73-92.

Bernor, R.L., Sun, B. \& Chen, Y. (2015b). Plesiohipparion shanxiense n. sp. from the Early Pleistocene (Nihowanian) of E. Shanxi, China . Bollettino della Societa Paleontologica Italiana, Modena, 54(3): 197-210.

Bernor, R.L., Tobien, H., Hayek, L.-A. \& Mittmann, H.-W. (1997). The Höwenegg Hipparionine Horses: Systematics, Stratigraphy, Taphonomy and Paleoenvironmental Context. Andrias, 10: $1-230$

Bernor, R.L. \& White, T.D. (2009). Systematics and Biogeography of "Cormohipparion” africanum, Early Vallesian (MN 9, ca. 10.5 Ma) of Bou Hanifia, Algeria; Papers on Geology, Vertebrate 
Paleontology, and Biostratigraphy in Honor of Michael O. Woodburne, In Albright III, L. B. (ed.). Bulletin, Museum of Northern Arizona, 65:635-658.

Bibi F., Hill A., Beech M. \& Yasin W. (2013) Late Miocene fossils from the Baynunah Formation, United Arab Emirates: Summary of a decade of new work. In: Wang X., Flynn L. J. Fortelius M. (ed) Fossil Mammals of Asia: Neogene Biostratigraphy and Chronology, Columbia Univ. Press, New York, p 583-594.

Bibi, F., Beech, M., Hill., A, \& Kraatz, B. (this volume-a). Fossil Localities of the Baynunah Formation. In F. Bibi, B. Kraatz, M. Beech, \& A. Hill (eds.) Sands of Time: Late Miocene Fossils from the Baynunah Formation, U.A.E. (pp. xxx). Cham: Springer.

Eisenmann V. (1995). What metapodial morphometry has to say about some Miocene hipparions. In Vrba E.S., Denton G.H., Partridge T.C. \& Burckle L.H. (eds), Paleoclimate and Evolution, with Emphasis on Human Origins, Yale University Press, New Haven: 148-163.

Eisenmann V., Alberdi M.T., de Giuli, C. \& Staesche U., (1988). Methodology. In Woodburne, M.O \& Sondaar, P.Y. (eds), Studying Fossil Horses, E.J. Brill Press, Leiden \& New York: 1-71. Eisenmann V. \& Sondaar P., (1998). Pliocene vertebrate locality of Calta, Ankara, Turkey. 7. Hipparion. Geodiversitas, 20(3): 408-430

Eisenmann, v. \& Whybrow, P. (1999). Hipparions from the late Miocene Baynunah Formation, Emirate of Abu Dhabi, United Arab Emirates. In Whybrow, P. \& Hill, A. (eds)., Fossil Vertebrates of Arabia, With Emphasis on the Late Miocene Faunas, Geology, and Palaeoenvironments of the Emirate of Abu Dhabi, United Arab Emirates, Yale University Press, New Haven: 234-253.

Fahlbusch, V. (1991). The meaning of MN zonations: considerations for a subdivision of the european continental Tertiary using mammals. Newsletters on Stratigraphy, 24: 159-73.

Gabunia, L.K., (1959). K Istorii Gipparionov (po materialam iz neogena SSSR) (in Russian), 1- 538, Tbilisi.

Getty R. (1982). The Anatomy of Domestic Animals. Saunders Company, Philadelphia, 1-1211. Gilbert, H. \& Bernor, R. L. Equidae. (2008). In Gilbert, H. \& Asfaw, B. (eds) Homo erectus - 
Pleistocene Evidence from the Middle Awash, Ethiopia. University of California Press, Berkeley: 133-166.

Gray J. E. (1821). On the natural arrangement on vertebrose animals. London Medical Repository record, 15: 296-310.

Gromova, V., (1952). Le genre Hipparion. Bureau de Recherches géologiques et Minières, C.E.D.P, 12: $1-288$.

Hill A., Whybrow P. J. \& Yasin W. (1999) History of palaeontological research in the Western Region of the Emirate of Abu Dhabi, United Arab Emirates. In: Whybrow P. J. Hill A. P. (ed) Fossil Vertebrates of Arabia, with Emphasis on the Late Miocene Faunas, Geology, and Palaeoenvironments of the Emirate of Abu Dhabi, United Arab Emirates, Yale University Press, New Haven, p 15-23.

Hill A., Bibi F., Beech M. \& Al-Tikriti W. Y. (2012) Before archaeology: life and environments in the Miocene of Abu Dhabi. In: Potts D. Hellyer P. (ed) Fifty Years of Emirates Archaeology, Ministry of Culture, Youth and Community Development, Abu Dhabi, p 20-23.

Kingston, J.D., 1999. Isotopes and environments of the Baynunah Formation, Emirate of Abu Dhabi, United Arab Emirates, in: Whybrow, P.J., Hill, A.P. (Eds.), Fossil Vertebrates of Arabia, with Emphasis on the Late Miocene Faunas, Geology, and Palaeoenvironments of the Emirate of Abu Dhabi, United Arab Emirates. Yale University Press, New Haven, pp. 354-372.

Koufos G. D. (1987) Study of the Pikermi hipparions. Part II. Comparisons and odontograms. Bulletin du Muséum national d'histoire naturelle, Section C, Sciences de la terre, paléontologie, géologie, minéralogie. 9(3): 327-363.

Koufos, G.D. \& Vlachou, T. (2005). Equidae (Mammalia, Perissodactyla) from the late Miocene of Akkasdagi, Turkey. In Sen S. (ed), Geology, mammals and environments at Akkasdagi, late Miocene of Central Anatolia. Geodiversitas 27(4): 633-705.

Koufos, G.D., Kostopoulos, D.S., Vlachou, T. \& Konidaris, G. (2011). A synoposis of the late Miocene Mammal Fauna of Samos Island, Aegean Sea, Greece. Geobios, 44(2-3): 237-251. Nickel R., Schummer A., Seiferle E., Wilkens H., Wille K.-H. \& Frewein J. (1986). The Anatomy of 
the Domestic Animals, Volume I: The Locomotor System. Verlag Paul Parey- Springer Verlag, Berlin: 1-499.

Owen, R. (1848). Description of the teeth and portions of jaws of two extinct anthracotheroid quadrupeds (Hyopotamus vectianus and Hyop. bovinus) discovered by the Marchioness of Hastings in the Eocene deposits of the N.W. coast of the Isle of Wight: with an attempt to develop Cuvier's idea of the classification of the pachyderms by the number of their toes. Quarterly Journal of the Geological Society of London, 4: 103-141.

Qiu, Z., Huang, W. \& Guo, Z. (1987). Chinese hipparionines from the Yushe Basin. Palaeontologica Sinica, Ser. C, 175 (25): 1-250.

Quinn J. H. (1955). Miocene Equidae of the Texas Gulf Coastal Plain. Bureau of Economic Geology, The University of Texas Publication, 5516: 1-102.

Scott, R.S. \& Maga, M. (2005). Paleoecology of the Akkasdagi hipparions (Mammalia, Equidae), late Miocene of Turkey, In Sen, S. (ed), Geology, mammals and environments at Akkasdagi, late Miocene of Central Anatolia. Geodiversitas 27(4): 809-830.

Uno, K. \& Bibi, F. (this volume). Stable isotope paleoecology of the Baynunah Formation. In F. Bibi, B. Kraatz, M. Beech, \& A. Hill (eds.) Sands of Time: Late Miocene Fossils from the Baynunah Formation, U.A.E. (pp. xxx). Cham: Springer.

Vlachou, D. \& Koufos, G. (2009). The late Miocene mammal fauanas of the Mytilinii Basin, Samos Island, Greece: New Collection. 11. Equidae. Beitrage Palaeontologie, 31:207-281.

Wood H. E. (1937). Perissodactyl suborders. Journal of Mammalogy, 18: 106-118.

Wolf, D. \& Bernor, R.L. (2013). Deciduous cheek teeth of the late Miocene (MN11) Dorn Duerkheim 1 hipparionine Horses. Palaeobiology and Palaeodiversity, 93:191-206.

Wolf, D., Bernor, R.L. \& Hussain, S.T.. (2013). Evolution, Biostratigraphy and Geochronology of Siwalik Hipparionine Horses. Palaeontographica, 300: 1-118. 


\section{Figure captions}

Figure 16.1 Main Baynunah localities from which remains of Hipparion have been collected.

Figure 16.2 A, Calcaneum maximum length (M1) versus maximum breadth (M6) all localities. B, Baynunah and Calta. 95\% ellipse of Höwenegg sample.

Figure 16.3 A, Astragalus maximum length (M1) versus distal articular breadth (M5) all localities. B, Baynunah and Calta. 95\% ellipse of Höwenegg sample.

Figure 16.4 A, MCIII maximum length (M1) versus distal articular breadth (M11) all localities. B, Baynunah, Akkasdagi and Calta. C, distal articular width (M11) versus saggital keel depth (M12), Baynunah, Akkasdagi and Calta. D, MTIII distal articular width (M11) versus saggital keel depth (M12), Baynunah, Akkasdagi and Calta, 95\% ellipse of Höwenegg sample.

Figure 16.5 A, 1PHIII maximum length (M1) versus proximal articular breadth (M4) all localities. B, Baynunah, Akkasdagi and Calta. 95\% ellipse of Höwenegg sample.

Figure 16.6 MCIII log10 ratio diagrams. A, Eurygnathohippus feibeli Compared to African Hipparionins, MCIII Log10 Ratio, Ho Std. B, Eurygnathohippus feibeli MCIII Compared to "Cormohipparion" africanum and Cremohipparion antelopinum, Log10 Ratio, Ho Std. C, Baynunah MCIII Compared to Bou Hanifia, Lothagam, Sahabi and the Siwaliks, Log10 Ratio, Ho Std. D, Baynunah and Akkasdagi "Plesiohipparion cf. longipes", China Plesiohipparion houfenense, log10 ratio, Ho Std.

Figure 16.7 1PHIII $\log 10$ ratio diagrams. A, Eurygnathohippus feibeli 1PHIII Compared to African Hipparionines $\log 10$ ratio, Ho Std. B, Eurygnathohippus feibeli 1PHIII Compared to Asian elongate 
limbed lineages $\log 10$ ratio, Ho Std. C, Baynunah 1PHIII comparison to Middle Awash, Lothagam, Sahabi and Maragheh Late Miocene Hipparions log10 ratio, Ho Std.

Figure 16.8 Maxillary Cheek Teeth. AUH 644, rt. P2 in A, labial and B, occlusal views. C, AUH1264, lt. M1 or 2, in labial view. D, AUH676, rt. M1, in occlusal view. Scale bar is $5 \mathrm{~cm}$.

Figure 16.9 Mandibles. AUH 270, type of "Hipparion" abudhabiense, in A, labial, and B, occlusal views. AUH1284 in C, labial and D, occlusal views. Shared scale bar for A, C, and D equals $10 \mathrm{~cm}$. Scale for B is $5 \mathrm{~cm}$.

Figure 16.10 Mandibular cheek teeth. AUH1712, rt. p4 (sampled for isotopes by K. Uno), in A, labial and B, occlusal views. AUH1535, 1t. m1 (sampled for isotopes by K. Uno), in C, labial and D, occlusal views.

Figure 16.11 Calcaneum. A, AUH1609, medial view. B, cranial view.

Figure 16.12 Astragalus. A, AUH88, lt., distal view. B, AUH340, rt. distal view.

Figure 16.13 MCIII. AUH1499, cranial view.

Figure 16.14 1PHIII. A, AUH324, caudal view. B, AUH1279, caudal view.

Figure 16.15 Right M3. AUH397 in A, labial and B, occlusal views.

Figure 16.16 Astragalus. AUH1695 in A, cranial and B, distal views.

Figure 16.17 Left p4. AUH 261, labial view. 


\section{Tables}

Table 16.1 Baynunah "Hipparion" taxonomic determinations. Abbreviations: mand, mandible; MC, metacarpal; MT, metatarsal; PH, phalanx, where 1PHIII refers to the first (i.e. proximal) phalanx on ray $3 ; \mathbf{t m}$, lower tooth; $\mathbf{t x}$, upper tooth.

\begin{tabular}{|c|c|c|c|c|c|c|}
\hline \multicolumn{2}{|c|}{ Specimen } & \multirow{2}{*}{$\begin{array}{l}\text { Locality } \\
\text { SHU } 1\end{array}$} & \multirow{2}{*}{$\begin{array}{l}\text { Element } \\
\text { tmm2 }\end{array}$} & \multirow{2}{*}{$\begin{array}{l}\text { Side } \\
\text { lt. }\end{array}$} & \multirow{2}{*}{$\begin{array}{l}\text { This Study } \\
" H " a b u\end{array}$} & \multirow[t]{2}{*}{$\begin{array}{l}\text { Eisenmann \& } \\
\text { Whybrow } 1999\end{array}$} \\
\hline AUH & $23 a$ & & & & & \\
\hline AUH & 28 & SHU 1 & MTIV & lt. & not seen & "H" sp. lg \\
\hline AUH & 46 & HMR 5 & txP2 & lt. & not seen & "H" sp. lg \\
\hline AUH & 72 & SHU 1 & tmm? & lt. & not seen & "H" $a b u$ \\
\hline AUH & 88 & SHU 1 & astragalus & lt. & "H" abu & \\
\hline AUH & 89 & SHU 1 & tibia & rt. & not seen & "H" sp. lg \\
\hline AUH & 115 & SHU 1 & $\mathrm{tmm} 2$ & lt. & "H" abu & "H" $a b u$ \\
\hline AUH & 144 & HMR 5 & tmp? & rt. & not seen & "H" sp. lg \\
\hline AUH & 165 & SHU 1 & 1PHIII & lt. & "H" abu & "H" abu \\
\hline AUH & 166 & SHU 1 & 1PHIII & & not seen & "H" abu \\
\hline AUH & 174 & HMR 1 & tmp? & rt. & not seen & "H" abu \\
\hline AUH & 176 & JDH 3 & MCIV & rt. & not seen & "H" sp. lg \\
\hline AUH & 177 & JDH 3 & MCIV & rt. & "H" abu & "H" sp. lg \\
\hline AUH & 178 & JDH 5 & txP3or4 & rt. & not seen & "H" sp. lg \\
\hline AUH & 196 & RDB 2 & astragalus & rt. & not seen & "H" sp. lg \\
\hline AUH & 197 & RDB 2 & cuneiform & lt. & "H" abu & \\
\hline AUH & 203 & RDB 2 & txM1or2 & rt. & not seen & "H" sp. lg \\
\hline AUH & 205 & RDB 2 & tmp4 & lt. & "H" abu & "H" sp. lg \\
\hline AUH & 210 & RDB 2 & txP4 & rt. & "H" abu? & "H" sp. lg \\
\hline AUH & 212 & RDB 2 & txM3 & lt. & "H" abu & "H" sp. lg \\
\hline AUH & 216 & RDB 2 & $2 \mathrm{tms}$ & rt. & not seen & "H" sp. lg \\
\hline AUH & 228 & SHU 4 & txM & lt. & not seen & "H" $a b u$ \\
\hline AUH & 229 & JBR 1 & txM1or2 & rt. & sectioned & "H" abu \\
\hline AUH & 230 & JBR 1 & txM1or2 & lt. & "H" abu & "H" abu \\
\hline AUH & $231 a$ & HMR 5 & txP3or4 & lt. & not seen & "H" abu \\
\hline AUH & 246 & JDH 3 & navicular & lt. & "H" abu & "H" sp. lg \\
\hline AUH & 260 & KIH 1 & txM? & rt. & not seen & "H" abu \\
\hline AUH & 261 & KIH 1 & tmp4 & lt. & "H" sp. sm & \\
\hline AUH & 264 & SHU 4 & txPx & lt. & not seen & "H" abu \\
\hline AUH & 265 & JDH 4 & tmp & rt. & not seen & "H" sp. lg \\
\hline AUH & $266 a$ & HMR 6 & tmm1 or 2 & lt. & not seen & "H" $a b u$ \\
\hline AUH & 267 & HMR 6 & 2PHIII & lt. & "H" abu & "H" sp. $\lg$ \\
\hline AUH & 317 & KIH 1 & magnum & rt. & "H" abu & \\
\hline AUH & 324 & THM 1 & 1PHIII & lt. & "H" abu & \\
\hline AUH & 326 & THM 1 & MTIII & rt. & "H" abu & \\
\hline AUH & 340 & HMR 5 & astragalus & rt. & "H" abu & \\
\hline AUH & 362 & MIM 1 & txP2 & lt. & "H" abu & \\
\hline AUH & 365 & HMR 1 & tmp2, tmp4 & lt. & "H" abu & \\
\hline AUH & 397 & SHU 2 & txM2frag, txM3 & rt. & "H"sp. sm & \\
\hline AUH & 399 & SHU 2 & 2PHIII & rt. & "H" $a b u$ & \\
\hline AUH & 439 & JDH 3 & MTIII & lt. & "H" abu & \\
\hline AUH & 452 & JDH 5 & mand, tmm1, tmp4 & rt. & "H" abu & "H" abu \\
\hline AUH & 644 & JDH 3 & txP2 & rt. & "H" abu & \\
\hline AUH & 647 & RDB 2 & astragalus & rt. & "H" abu & \\
\hline AUH & 648 & RDB 2 & femur & lt. & "H" abu & \\
\hline AUH & 649 & RDB 2 & tmm1 & lt. & "H" abu & \\
\hline AUH & 676 & JBR 1 & txM1 & rt. & "H" abu & \\
\hline AUH & 677 & SHU 4 & tmm1 & lt. & "H" abu & \\
\hline
\end{tabular}




\begin{tabular}{|c|c|c|c|c|c|c|}
\hline AUH & 699 & SHU 4 & txP2 & rt. & "H" $a b u$ & \\
\hline AUH & 704 & JDH 3 & tmml & lt. & "H" $a b u$ & \\
\hline AUH & 786 & SHU 4 & $\operatorname{tmp} 2$ & lt. & "H" abu & \\
\hline AUH & 788 & SHU 4 & navicular & lt. & "H" $a b u$ & \\
\hline AUH & 1122 & RDB 1 & tmp4 & lt. & "H" $a b u$ & \\
\hline AUH & 1146 & RDB 1 & mand & rt. & "H" $a b u$ & \\
\hline AUH & 1248 & KIH 3 & MCIII & lt. & "H" $a b u$ & \\
\hline AUH & 1264 & GAA 7 & $\begin{array}{l}\text { txM1, txM2, txM3, } \\
\text { txM3, txP2, txP4, } \\
\text { txM1, txP4 }\end{array}$ & lt. \& rt. & "H" abu & \\
\hline AUH & 1279 & HMR 5 & 1PHIII & lt. & "H" $a b u$ & \\
\hline AUH & 1284 & HMR 1 & $\begin{array}{l}\text { tmm2, tmm3, tmp2, } \\
\text { tmp3, tmp4 }\end{array}$ & lt. \& rt. & "H" $a b u$ & \\
\hline AUH & 1295 & HMR 5 & txP2 & rt. & "H" abu & \\
\hline AUH & 1311 & HAR 1 & txP4 & rt. & "H" abu & \\
\hline AUH & 1465 & SHU 2 & tmm1 & rt. & "H" $a b u$ & \\
\hline AUH & 1483 & SHU 4 & tmm3 & rt. & "H" $a b u$ & \\
\hline AUH & 1491 & HMR 1 & tibia & 1t. & "H" $a b u$ & \\
\hline AUH & 1499 & HMR 1 & MCIII & lt. & "H" $a b u$ & \\
\hline AUH & 1535 & GAA 2 & tmm1 & lt. & "H" $a b u$ & \\
\hline AUH & 1549 & GAA 1 & tmp4 & lt. & "H" $a b u$ & \\
\hline AUH & 1558 & GAA 1 & tmm3 & lt. & "H" $a b u$ & \\
\hline AUH & 1560 & GAA 1 & tmm2 & rt. & "H" abu & \\
\hline AUH & 1566 & GAA 3 & txM2 & rt. & "H" abu & \\
\hline AUH & 1571 & GAA 5 & MTIII & rt. & "H" $a b u$ & \\
\hline AUH & 1581 & HAD 1 & 2PHIII & lt. & "H" $a b u$ & \\
\hline AUH & 1584 & HAD 1 & MTIV & 1t. & "H" $a b u$ & \\
\hline AUH & 1595 & HAD 3 & MTIV & rt. & "H" abu & \\
\hline AUH & 1596 & HAD 3 & txM3 & lt. & "H" $a b u$ & \\
\hline AUH & 1607 & BYN 1 & MCIIorIV & rt. & "H" $a b u$ & \\
\hline AUH & 1609 & BYN 1 & calcaneum & rt. & "H" $a b u$ & \\
\hline AUH & 1610 & BYN 1 & lunate & rt. & "H" abu & \\
\hline AUH & 1695 & MTL 2 & astragalus & lt. & "H" sp. sm & \\
\hline AUH & 1712 & JBR & tmp4 & rt. & "H" $a b u$ & \\
\hline AUH & 1751 & SHU 4 & 1PHIIorIV & & "H" $a b u$ & \\
\hline AUH & 1758 & RUW SE & MTIV & rt. & "H" $a b u$ & \\
\hline AUH & 1763 & RUW SE & tmml & lt. & "H" $a b u$ & \\
\hline AUH & 1777 & RUW SE & tmm3 & rt. & "H" $a b u$ & \\
\hline AUH & 1792 & SHU 12 & MCIII & lt. & "H" $a b u$ & \\
\hline BMNH & M50661 & JBR 2 & tmp3or4 & lt. & not seen & "H" $a b u$ \\
\hline BMNH & M50662 & JBR 2 & tmp2 & lt. & not seen & "H" abu \\
\hline BMNH & M50663 & JBR 2 & tmm? & rt. & not seen & "H" $a b u$ \\
\hline BMNH & M50664 & JBR 2 & txP2frag & lt. & not seen & "H" sp. lg \\
\hline BMNH & M50665 & JBR 2 & radius & lt. & not seen & "H" abu \\
\hline BMNH & M50667 & JBR 2 & pelvis frag & lt. & not seen & "H" sp. lg \\
\hline
\end{tabular}

Table 16.2 Measurements on Baynunah “Hipparion” teeth. Measurement numbers (M1, M2, M3, etc.) refer to those published by Eisenmann et al. (1988) and Bernor et al. (1997). See those publications for postcranial measurements. Mandibular measurements used here: M2 = muzzle length. M3 = premolar length. M4 = molar length. M5 = lower cheeck teeth length. M7 = muzzle breadth. 
Tooth measurements: for upper teeth: $\mathrm{Ml}=$ length at occlusal level. $\mathrm{M} 2=$ length $10 \mathrm{~mm}$ above the tooth's base (in isolated teeth only). M3 = width at occlusal level, taken across mesostyle-protocone. M4 = width $10 \mathrm{~mm}$ above the tooth's base (in isolated teeth only). M5 = crown height measured along the mesostyle. M6 = number of plications on the anterior face of the prefossette. M7 = number of plications on the posterior face of the prefossette. M8 = number of plications on the anterior face of the postfossette. $\mathrm{M} 9=$ number of pli cations on the posterior face of the postfossette. $\mathrm{M} 10=$ protocone length. $\mathrm{M} 11=$ protocone width. For lower teeth: $\mathrm{Ml}=$ length at occlusal level. $\mathrm{M} 2=$ length $10 \mathrm{~mm}$ above the tooth's base (in isolated teeth only). M3 = length of metaconid-metastylid (= 'double-knot' of Eisenmann et al., 1988). M4 = length of the prefossette. M5 = length of the postfossette. M6 = W1, width of tooth across plane of ectoflexid/linguaflexid. M7 = width $10 \mathrm{~mm}$ above base. $\mathrm{M} 8=$ width across plane of metaconid and enamel band labial to protoconid. M9 = width across plane of metastylid and enam el band labial to hypoconid. M10 = crown height as measured from base to occlusal level on mesial face of the tooth. Element abbreviations as in Table 16.1.

\begin{tabular}{|c|c|c|c|c|c|c|c|c|c|c|c|c|c|c|c|c|}
\hline $\begin{array}{l}\text { Specim } \\
\text { en }\end{array}$ & Taxon & Element & $\begin{array}{l}\text { Sid } \\
\text { e }\end{array}$ & M1 & M2 & M3 & M4 & M5 & M6 & M7 & M8 & M9 & $\begin{array}{l}\text { M1 } \\
\text { 0 }\end{array}$ & $\begin{array}{l}\text { M1 } \\
1\end{array}$ & $\begin{array}{l}\text { M1 } \\
2\end{array}$ & $\begin{array}{l}\text { M1 } \\
3\end{array}$ \\
\hline $\begin{array}{l}\text { AUH } \\
1279\end{array}$ & "H"abu & 1PHIII & lt. & 60.7 & 54.0 & $\begin{array}{l}26 . \\
3\end{array}$ & $\begin{array}{l}36 . \\
7\end{array}$ & 26.5 & 26.8 & $\begin{array}{l}30 . \\
0\end{array}$ & $\begin{array}{l}18 . \\
0\end{array}$ & & $\begin{array}{l}35 . \\
0\end{array}$ & $\begin{array}{l}35 . \\
6\end{array}$ & $\begin{array}{l}19 . \\
7\end{array}$ & $\begin{array}{l}17 . \\
1\end{array}$ \\
\hline $\begin{array}{l}\text { AUH } \\
165\end{array}$ & "H"abu & 1PHIII & lt. & 62.8 & 59.0 & $\begin{array}{l}25 . \\
5\end{array}$ & $\begin{array}{l}33 . \\
6\end{array}$ & 27.9 & 30.6 & $\begin{array}{l}30 . \\
8\end{array}$ & $\begin{array}{l}16 . \\
6\end{array}$ & & $\begin{array}{l}42 . \\
0\end{array}$ & $\begin{array}{l}45 . \\
3\end{array}$ & $\begin{array}{l}16 . \\
2\end{array}$ & $\begin{array}{l}12 . \\
3\end{array}$ \\
\hline $\begin{array}{l}\text { AUH } \\
324\end{array}$ & "H"abu & 1PHIII & lt. & 63.9 & 54.9 & $\begin{array}{l}25 . \\
9\end{array}$ & $\begin{array}{l}37 . \\
2\end{array}$ & 29.0 & 29.7 & $\begin{array}{l}30 . \\
8\end{array}$ & $\begin{array}{l}18 . \\
3\end{array}$ & $\begin{array}{l}29 . \\
4\end{array}$ & $\begin{array}{l}42 . \\
4\end{array}$ & $\begin{array}{l}46 . \\
8\end{array}$ & $\begin{array}{l}16 . \\
8\end{array}$ & $\begin{array}{l}16 . \\
2\end{array}$ \\
\hline $\begin{array}{l}\text { AUH } \\
1751\end{array}$ & "H"abu & 1PHIIorIV & 3 & 30.0 & 18.1 & $\begin{array}{l}11 . \\
6\end{array}$ & 9.0 & 16.1 & 11.9 & & & & & & & \\
\hline $\begin{array}{l}\text { AUH } \\
1581\end{array}$ & "H"abu & 2PHIII & lt. & 39.1 & 29.6 & $\begin{array}{l}28 . \\
8\end{array}$ & $\begin{array}{l}35 . \\
3\end{array}$ & 32.8 & 31.6 & & & & & & & \\
\hline $\begin{array}{l}\text { AUH } \\
267\end{array}$ & "H"abu & 2PHIII & lt. & 37.6 & 28.2 & $\begin{array}{l}28 . \\
8\end{array}$ & $\begin{array}{l}34 . \\
1\end{array}$ & 23.3 & 33.0 & & & & & & & \\
\hline $\begin{array}{l}\text { AUH } \\
399\end{array}$ & "H"abu & 2PHIII & rt. & 38.2 & & $\begin{array}{l}26 . \\
4\end{array}$ & $\begin{array}{l}31 . \\
8\end{array}$ & & 31.6 & & & & & & & \\
\hline $\begin{array}{l}\text { AUH } \\
340\end{array}$ & "H"abu & astragalus & rt. & 54.4 & 53.5 & $\begin{array}{l}27 . \\
3\end{array}$ & & 42.9 & 30.9 & $\begin{array}{l}44 . \\
2\end{array}$ & & & & & & \\
\hline $\begin{array}{l}\text { AUH } \\
88\end{array}$ & "H"abu & astragalus & lt. & 51.4 & 50.0 & $\begin{array}{l}26 . \\
9\end{array}$ & $\begin{array}{l}50 . \\
9\end{array}$ & 43.1 & 29.7 & $\begin{array}{l}40 . \\
1\end{array}$ & & & & & & \\
\hline $\begin{array}{l}\text { AUH } \\
647\end{array}$ & "H"abu & astragalus & rt. & 58.7 & & $\begin{array}{l}36 . \\
0\end{array}$ & & & & & & & & & & \\
\hline $\begin{array}{l}\text { AUH } \\
1609\end{array}$ & "H"abu & calcaneum & rt. & 99.4 & 61.9 & $\begin{array}{l}20 . \\
7\end{array}$ & & 47.8 & 50.0 & $\begin{array}{l}44 . \\
7\end{array}$ & & & & & & \\
\hline
\end{tabular}




\begin{tabular}{|c|c|c|c|c|c|c|c|c|c|c|c|c|c|c|c|c|c|}
\hline $\begin{array}{l}\text { AUH } \\
197\end{array}$ & "H"abu & cuneiform & lt. & 12.1 & 37.4 & $\begin{array}{l}33 . \\
6\end{array}$ & & & & & & & & & & & \\
\hline $\begin{array}{l}\text { AUH } \\
648\end{array}$ & "H"abu & femur & lt. & & & $\begin{array}{l}37 . \\
6\end{array}$ & & $\begin{array}{l}107 . \\
8\end{array}$ & $\begin{array}{l}107 . \\
8\end{array}$ & & & & & & & & \\
\hline $\begin{array}{l}\text { AUH } \\
1610\end{array}$ & "H"abu & lunate & rt. & 20.9 & 23.9 & $\begin{array}{l}20 . \\
6\end{array}$ & $\begin{array}{l}28 . \\
2\end{array}$ & & & & & & & & & & \\
\hline $\begin{array}{l}\text { AUH } \\
317\end{array}$ & "H"abu & magnum & rt. & 10.6 & 35.1 & $\begin{array}{l}27 . \\
4\end{array}$ & & & & & & & & & & & \\
\hline $\begin{array}{l}\text { AUH } \\
1146\end{array}$ & "H"abu & mandible & rt. & & & $\begin{array}{l}88 . \\
7\end{array}$ & $\begin{array}{l}60 . \\
8\end{array}$ & & & & & & & $\begin{array}{l}74 . \\
9\end{array}$ & $\begin{array}{l}49 . \\
2\end{array}$ & & \\
\hline $\begin{array}{l}\text { AUH } \\
1284\end{array}$ & "H"abu & mandible & rt. & & 91.8 & $\begin{array}{l}73 . \\
5\end{array}$ & $\begin{array}{l}70 . \\
1\end{array}$ & $\begin{array}{l}144 . \\
7\end{array}$ & & $\begin{array}{l}51 . \\
7\end{array}$ & & & & & & & \\
\hline $\begin{array}{l}\text { AUH } \\
1284\end{array}$ & "H"abu & mandible & lt. & & & $\begin{array}{l}70 . \\
3\end{array}$ & $\begin{array}{l}69 . \\
6\end{array}$ & $\begin{array}{l}145 . \\
9\end{array}$ & & & & & $\begin{array}{l}89 . \\
1\end{array}$ & $\begin{array}{l}65 . \\
2\end{array}$ & $\begin{array}{l}50 . \\
6\end{array}$ & $\begin{array}{l}58 . \\
6\end{array}$ & $\begin{array}{l}38 . \\
5\end{array}$ \\
\hline $\begin{array}{l}\text { AUH } \\
452\end{array}$ & "H"abu & mandible & rt. & & & $\begin{array}{l}67 . \\
6\end{array}$ & & & & & & & & $\begin{array}{l}63 . \\
5\end{array}$ & $\begin{array}{l}43 . \\
3\end{array}$ & & \\
\hline $\begin{array}{l}\text { AUH } \\
1499\end{array}$ & "H"abu & MCIII & lt. & $\begin{array}{l}247 . \\
9\end{array}$ & $\begin{array}{l}246 . \\
6\end{array}$ & $\begin{array}{l}30 . \\
3\end{array}$ & & & 28.2 & $\begin{array}{l}28 . \\
6\end{array}$ & & & $\begin{array}{l}35 . \\
9\end{array}$ & $\begin{array}{l}34 . \\
5\end{array}$ & $\begin{array}{l}28 . \\
6\end{array}$ & $\begin{array}{l}23 . \\
7\end{array}$ & $\begin{array}{l}26 . \\
9\end{array}$ \\
\hline $\begin{array}{l}\text { AUH } \\
1248\end{array}$ & "H"abu & MCIII & lt. & & & & & 37.1 & 25.1 & $\begin{array}{l}29 . \\
5\end{array}$ & $\begin{array}{l}13 . \\
1\end{array}$ & 5.1 & & & & & \\
\hline $\begin{array}{l}\text { AUH } \\
1792\end{array}$ & "H"abu & MCIII & lt. & & & & & & & & & & $\begin{array}{l}33 . \\
2\end{array}$ & $\begin{array}{l}32 . \\
0\end{array}$ & $\begin{array}{l}24 . \\
7\end{array}$ & $\begin{array}{l}21 . \\
6\end{array}$ & \\
\hline $\begin{array}{l}\text { AUH } \\
1607\end{array}$ & "H"abu & MCIIorIV & rt. & & & $\begin{array}{l}10 . \\
2\end{array}$ & $\begin{array}{l}13 . \\
6\end{array}$ & & & & & & & & & & \\
\hline $\begin{array}{l}\text { AUH } \\
177\end{array}$ & "H"abu & MCIV & rt. & & & $\begin{array}{l}11 . \\
6\end{array}$ & $\begin{array}{l}16 . \\
1\end{array}$ & 8.4 & 17.5 & & & & & & & & \\
\hline $\begin{array}{l}\text { AUH } \\
439\end{array}$ & "H"abu & MTIII & lt. & & & $\begin{array}{l}31 . \\
2\end{array}$ & $\begin{array}{l}38 . \\
1\end{array}$ & 39.2 & 36.9 & $\begin{array}{l}38 . \\
8\end{array}$ & & & & & & & \\
\hline $\begin{array}{l}\text { AUH } \\
1571\end{array}$ & "H"abu & MTIII & rt. & & & & & & & & & & $\begin{array}{l}33 . \\
0\end{array}$ & $\begin{array}{l}33 . \\
0\end{array}$ & $\begin{array}{l}27 . \\
2\end{array}$ & $\begin{array}{l}22 . \\
7\end{array}$ & $\begin{array}{l}24 . \\
8\end{array}$ \\
\hline $\begin{array}{l}\text { AUH } \\
326\end{array}$ & "H"abu & MTIII & rt. & & & & & & & & & & $\begin{array}{l}33 . \\
0\end{array}$ & $\begin{array}{l}31 . \\
5\end{array}$ & $\begin{array}{l}26 . \\
4\end{array}$ & $\begin{array}{l}22 . \\
9\end{array}$ & $\begin{array}{l}24 . \\
2\end{array}$ \\
\hline $\begin{array}{c}\text { AUH } \\
1584\end{array}$ & "H"abu & MTIV & lt. & $\begin{array}{l}214 . \\
4\end{array}$ & 9.5 & $\begin{array}{l}12 . \\
9\end{array}$ & $\begin{array}{l}20 . \\
0\end{array}$ & 9.4 & 20.0 & & & & & & & & \\
\hline $\begin{array}{l}\text { AUH } \\
1595\end{array}$ & "H"abu & MTIV & rt. & & & $\begin{array}{l}17 . \\
8\end{array}$ & $\begin{array}{l}23 . \\
8\end{array}$ & & & & & & & & & & \\
\hline $\begin{array}{l}\text { AUH } \\
1758\end{array}$ & "H"abu & MTIV & rt. & & & $\begin{array}{l}14 . \\
7\end{array}$ & $\begin{array}{l}22 . \\
2\end{array}$ & & & & & & & & & & \\
\hline $\begin{array}{l}\text { AUH } \\
788\end{array}$ & "H"abu & navicular & lt. & 12.8 & 43.8 & $\begin{array}{l}31 . \\
7\end{array}$ & & & & & & & & & & & \\
\hline $\begin{array}{l}\text { AUH } \\
246\end{array}$ & "H"abu & navicular & lt. & 22.2 & 39.0 & $\begin{array}{l}29 . \\
9\end{array}$ & & & & & & & & & & & \\
\hline $\begin{array}{l}\text { AUH } \\
1491\end{array}$ & "H"abu & tibia & lt. & & & & & & & $\begin{array}{l}39 . \\
7\end{array}$ & $\begin{array}{l}40 \\
8\end{array}$ & & & & & & \\
\hline $\begin{array}{l}\text { AUH } \\
1284\end{array}$ & "H"abu & tmc & rt. & 15.9 & & & & & 8.1 & & & & & & & & \\
\hline
\end{tabular}




\begin{tabular}{|c|c|c|c|c|c|c|c|c|c|c|c|c|c|}
\hline $\begin{array}{l}\text { AUH } \\
1284\end{array}$ & "H"abu & $\mathrm{tmm} 1$ & rt. & 19.6 & & & & & & & & & \\
\hline AUH & & & & & & & & & & & & & 51. \\
\hline 1465 & "H"abu & $\mathrm{tmm} 1$ & rt. & 27.7 & 22.7 & & & & & & & & 5 \\
\hline $\begin{array}{l}\text { AUH } \\
1535\end{array}$ & "H"abu & tmm1 & lt. & 24.4 & 20.0 & $\begin{array}{l}14 . \\
2\end{array}$ & 7.1 & 10.6 & 12.3 & $\begin{array}{l}11 . \\
7\end{array}$ & $\begin{array}{l}10 . \\
1\end{array}$ & 9.9 & $\begin{array}{l}46 . \\
8\end{array}$ \\
\hline $\begin{array}{l}\text { AUH } \\
1763\end{array}$ & "H"abu & $\mathrm{tmm} 1$ & lt. & 22.2 & 18.5 & $\begin{array}{l}11 . \\
1\end{array}$ & 6.4 & 8.5 & 10.8 & $\begin{array}{l}11 . \\
8\end{array}$ & 9.0 & 9.5 & $\begin{array}{l}43 . \\
8\end{array}$ \\
\hline $\begin{array}{l}\text { AUH } \\
452\end{array}$ & "H"abu & tmm1 & rt. & 21.3 & & & & & 12.6 & & & $\begin{array}{l}13 . \\
7\end{array}$ & $\begin{array}{l}10 . \\
9\end{array}$ \\
\hline $\begin{array}{l}\text { AUH } \\
649\end{array}$ & "H"abu & tmm1 & lt. & & & $\begin{array}{l}14 . \\
1\end{array}$ & 8.5 & & & $\begin{array}{l}12 . \\
1\end{array}$ & $\begin{array}{l}11 . \\
1\end{array}$ & & $\begin{array}{l}33 . \\
0\end{array}$ \\
\hline $\begin{array}{l}\text { AUH } \\
677\end{array}$ & "H"abu & tmm1 & lt. & 22.5 & 20.5 & $\begin{array}{l}11 . \\
1\end{array}$ & & & 9.3 & $\begin{array}{l}12 . \\
3\end{array}$ & 9.8 & $\begin{array}{l}10 . \\
4\end{array}$ & $\begin{array}{l}50 . \\
7\end{array}$ \\
\hline $\begin{array}{l}\text { AUH } \\
704\end{array}$ & "H"abu & tmm1 & lt. & 22.4 & 19.6 & $\begin{array}{l}13 . \\
0\end{array}$ & & 6.7 & 11.5 & $\begin{array}{l}11 . \\
8\end{array}$ & & $\begin{array}{l}10 . \\
6\end{array}$ & $\begin{array}{l}28 . \\
1\end{array}$ \\
\hline $\begin{array}{l}\text { AUH } \\
115\end{array}$ & "H"abu & $\mathrm{tmm} 2$ & lt. & 21.0 & & $\begin{array}{l}11 . \\
5\end{array}$ & 6.4 & 8.6 & & $\begin{array}{l}10 . \\
3\end{array}$ & $\begin{array}{l}11 . \\
4\end{array}$ & $\begin{array}{l}10 . \\
8\end{array}$ & $\begin{array}{l}38 . \\
5\end{array}$ \\
\hline $\begin{array}{l}\text { AUH } \\
1284\end{array}$ & "H"abu & $\mathrm{tmm} 2$ & rt. & & & & & & & & & & \\
\hline $\begin{array}{l}\text { AUH } \\
1560\end{array}$ & "H"abu & $\mathrm{tmm} 2$ & rt. & & 24.1 & $\begin{array}{l}14 . \\
3\end{array}$ & 7.2 & 8.3 & 10.8 & $\begin{array}{l}13 . \\
7\end{array}$ & $\begin{array}{l}12 . \\
8\end{array}$ & $\begin{array}{l}11 . \\
0\end{array}$ & $\begin{array}{l}30 . \\
2\end{array}$ \\
\hline $\begin{array}{l}\mathrm{AUH} \\
23 \mathrm{a}\end{array}$ & "H"abu & $\mathrm{tmm} 2$ & lt. & & & $\begin{array}{l}13 . \\
9\end{array}$ & 7.3 & 9.3 & & & & & $\begin{array}{l}54 . \\
4\end{array}$ \\
\hline $\begin{array}{l}\text { AUH } \\
1284\end{array}$ & "H"abu & tmm3 & rt. & & & & & & & & & & \\
\hline $\begin{array}{l}\text { AUH } \\
1483\end{array}$ & "H"abu & $\mathrm{tmm} 3$ & rt. & & 22.8 & $\begin{array}{l}11 . \\
5\end{array}$ & 5.9 & 7.1 & 9.5 & $\begin{array}{l}10 . \\
0\end{array}$ & $\begin{array}{l}10 . \\
9\end{array}$ & $\begin{array}{l}10 . \\
0\end{array}$ & $\begin{array}{l}30 . \\
3\end{array}$ \\
\hline $\begin{array}{l}\text { AUH } \\
1558\end{array}$ & "H"abu & $\mathrm{tmm} 3$ & lt. & 22.4 & 25.8 & 8.8 & & & 8.1 & 8.8 & 5.9 & 5.8 & $\begin{array}{l}46 . \\
0\end{array}$ \\
\hline $\begin{array}{l}\text { AUH } \\
1777\end{array}$ & "H"abu & $\mathrm{tmm} 3$ & rt. & 23.9 & 24.3 & $\begin{array}{l}11 . \\
0\end{array}$ & 7.2 & 7.5 & 9.3 & $\begin{array}{l}10 . \\
8\end{array}$ & 9.9 & 8.2 & $\begin{array}{l}41 . \\
7\end{array}$ \\
\hline $\begin{array}{l}\text { AUH } \\
1284\end{array}$ & "H"abu & tmp2 & rt. & 26.5 & & $\begin{array}{l}13 . \\
2\end{array}$ & 6.7 & 9.9 & & & & & \\
\hline $\begin{array}{l}\text { AUH } \\
365\end{array}$ & "H"abu & tmp2 & lt. & & & $\begin{array}{l}11 . \\
6\end{array}$ & 7.1 & 9.8 & & $\begin{array}{l}12 . \\
6\end{array}$ & & $\begin{array}{l}13 . \\
2\end{array}$ & $\begin{array}{l}21 . \\
2\end{array}$ \\
\hline $\begin{array}{l}\text { AUH } \\
786\end{array}$ & "H"abu & tmp2 & lt. & 25.7 & 23.3 & $\begin{array}{l}10 . \\
0\end{array}$ & 5.7 & 8.2 & 13.8 & $\begin{array}{l}13 . \\
2\end{array}$ & $\begin{array}{l}10 . \\
1\end{array}$ & $\begin{array}{l}13 . \\
5\end{array}$ & $\begin{array}{l}10 . \\
9\end{array}$ \\
\hline $\begin{array}{l}\text { AUH } \\
1284\end{array}$ & "H"abu & tmp3 & rt. & 20.6 & & $\begin{array}{l}15 . \\
4\end{array}$ & 8.5 & 8.8 & & & & & \\
\hline $\begin{array}{l}\text { AUH } \\
1122\end{array}$ & "H"abu & tmp4 & lt. & & & $\begin{array}{l}14 . \\
2\end{array}$ & 6.8 & 11.8 & 12.2 & $\begin{array}{l}17 . \\
4\end{array}$ & $\begin{array}{l}13 . \\
2\end{array}$ & & $\begin{array}{l}43 . \\
9\end{array}$ \\
\hline $\begin{array}{l}\text { AUH } \\
1284\end{array}$ & "H"abu & tmp4 & rt. & 21.1 & & $\begin{array}{l}12 . \\
9\end{array}$ & & & & & & & \\
\hline $\begin{array}{l}\text { AUH } \\
365\end{array}$ & "H"abu & tmp4 & lt. & & 24.3 & $\begin{array}{l}13 . \\
3\end{array}$ & & 12.3 & 13.3 & $\begin{array}{l}15 . \\
4\end{array}$ & $\begin{array}{l}11 . \\
3\end{array}$ & & $\begin{array}{l}48 . \\
0\end{array}$ \\
\hline
\end{tabular}




\begin{tabular}{|c|c|c|c|c|c|c|c|c|c|c|c|c|c|c|}
\hline $\begin{array}{l}\text { AUH } \\
452\end{array}$ & "H"abu & tmp4 & rt. & 21.5 & & & & & 11.9 & & & $\begin{array}{l}13 . \\
3\end{array}$ & 8.5 & \\
\hline $\begin{array}{l}\text { AUN1 } \\
549\end{array}$ & "H"abu & tmp4 & lt. & 26.3 & & $\begin{array}{l}12 . \\
8\end{array}$ & & & & & 8.3 & 8.8 & $\begin{array}{l}48 . \\
6\end{array}$ & \\
\hline $\begin{array}{l}\text { AUH } \\
205\end{array}$ & "H"abu & tmp4 & lt. & 25.9 & & $\begin{array}{l}11 . \\
7\end{array}$ & 8.3 & 10.0 & & & & & $\begin{array}{l}48 . \\
3\end{array}$ & \\
\hline $\begin{array}{l}\text { AUH } \\
1712\end{array}$ & "H"abu & tmp4 & rt. & 28.8 & 23.4 & $\begin{array}{l}16 . \\
3\end{array}$ & 9.1 & 12.3 & 19.0 & $\begin{array}{l}16 . \\
4\end{array}$ & $\begin{array}{l}15 . \\
4\end{array}$ & $\begin{array}{l}14 . \\
2\end{array}$ & $\begin{array}{l}54 . \\
6\end{array}$ & \\
\hline $\begin{array}{l}\text { AUN1 } \\
264\end{array}$ & "H"abu & txM1 & rt. & 24.0 & 20.0 & $\begin{array}{l}21 \\
4\end{array}$ & $\begin{array}{l}20 . \\
7\end{array}$ & 48.1 & 2 & 4 & 3 & 1 & 5.8 & 3.7 \\
\hline $\begin{array}{l}\text { AUH } \\
1264\end{array}$ & "H"abu & txM1 & lt. & 23.7 & 20.0 & $\begin{array}{l}23 \\
2\end{array}$ & $\begin{array}{l}22 . \\
5\end{array}$ & 45.7 & 5 & 6 & 3 & 1 & 6.1 & 3.6 \\
\hline $\begin{array}{l}\text { AUH } \\
676\end{array}$ & "H"abu & txM1 & rt. & 23.0 & 21.3 & $\begin{array}{l}22 . \\
9\end{array}$ & $\begin{array}{l}25 . \\
3\end{array}$ & 59.7 & 0 & 0 & 0 & 0 & 7.7 & 4.3 \\
\hline $\begin{array}{l}\text { AUH } \\
230\end{array}$ & "H"abu & txM1or2 & lt. & 19.8 & 17.0 & $\begin{array}{l}20 . \\
1\end{array}$ & $\begin{array}{l}20 . \\
0\end{array}$ & 46.2 & 2 & 3 & 2 & 2 & 6.0 & 3.0 \\
\hline $\begin{array}{c}\text { AUH } \\
1264\end{array}$ & "H"abu & txM2 & lt. & & & & & 49.3 & 0 & 5 & & & & \\
\hline $\begin{array}{l}\text { AUH } \\
1566\end{array}$ & "H"abu & txM2 & rt. & & & $\begin{array}{l}23 \\
4\end{array}$ & $\begin{array}{l}26 . \\
4\end{array}$ & 55.7 & 3 & 3 & & & 8.2 & 3.6 \\
\hline $\begin{array}{l}\text { AUH } \\
397 a\end{array}$ & "H"abu & txM2frag & rt. & & & & & 47.8 & & 3 & 1 & 0 & & \\
\hline $\begin{array}{c}\text { AUH } \\
1264\end{array}$ & "H"abu & txM3 & lt. & 21.6 & 18.8 & $\begin{array}{l}16 . \\
8\end{array}$ & $\begin{array}{l}18 . \\
9\end{array}$ & 41.5 & & & & & 4.6 & 3.4 \\
\hline $\begin{array}{l}\text { AUH } \\
1264\end{array}$ & "H"abu & txM3 & rt. & 21.7 & 19.5 & $\begin{array}{l}16 . \\
4\end{array}$ & $\begin{array}{l}18 . \\
6\end{array}$ & 42.6 & 0 & 0 & & & 5.6 & 3.1 \\
\hline $\begin{array}{l}\text { AUH } \\
1596\end{array}$ & "H"abu & txM3 & lt. & 12.2 & 23.7 & $\begin{array}{l}18 . \\
8\end{array}$ & $\begin{array}{l}19 . \\
2\end{array}$ & 28.6 & 1 & 5 & 2 & 2 & 9.2 & 4.7 \\
\hline $\begin{array}{l}\text { AUH } \\
212\end{array}$ & "H"abu & txM3 & lt. & 26.2 & 25.4 & & & 52.4 & & & & & & \\
\hline $\begin{array}{l}\text { AUH } \\
1264\end{array}$ & "H"abu & txP2 & lt. & & & & & & 4 & 4 & & & & \\
\hline $\begin{array}{l}\text { AUH } \\
1295\end{array}$ & "H"abu & txP2 & rt. & & & $\begin{array}{l}22 . \\
0\end{array}$ & $\begin{array}{l}19 . \\
8\end{array}$ & 35.8 & 1 & 3 & 3 & 1 & 6.8 & 5.4 \\
\hline $\begin{array}{l}\text { AUH } \\
362\end{array}$ & "H"abu & txP2 & lt. & & & $\begin{array}{l}21 \\
6\end{array}$ & $\begin{array}{l}18 . \\
9\end{array}$ & 39.4 & 3 & 1 & & 2 & 6.5 & 5.8 \\
\hline $\begin{array}{l}\text { AUH } \\
644\end{array}$ & "H"abu & txP2 & rt. & 30.5 & 27.3 & $\begin{array}{l}22 \\
4\end{array}$ & $\begin{array}{l}21 . \\
7\end{array}$ & 18.2 & 1 & 2 & 3 & 0 & 6.7 & 7.1 \\
\hline $\begin{array}{l}\text { AUH } \\
699\end{array}$ & "H"abu & txP2 & rt. & & & $\begin{array}{l}18 . \\
9\end{array}$ & & 44.4 & & & & & 7.2 & 4.0 \\
\hline $\begin{array}{l}\text { AUH } \\
1311\end{array}$ & "H"abu & txP4 & rt. & 24.1 & 22.4 & $\begin{array}{l}24 . \\
2\end{array}$ & $\begin{array}{l}22 . \\
8\end{array}$ & 32.5 & 4 & 6 & 7 & 1 & 6.4 & 4.3 \\
\hline $\begin{array}{l}\text { AUN1 } \\
264\end{array}$ & "H"abu & txP4 & 1t. & 26.1 & 20.4 & $\begin{array}{l}25 \\
3\end{array}$ & $\begin{array}{l}20 . \\
8\end{array}$ & 48.8 & 3 & 4 & & 1 & 6.8 & 4.6 \\
\hline $\begin{array}{c}\text { AUH } \\
1264\end{array}$ & "H"abu & txP4 & It. & & & & & & & & & & & \\
\hline
\end{tabular}




\begin{tabular}{|c|c|c|c|c|c|c|c|c|c|c|c|c|c|}
\hline $\begin{array}{l}\text { AUH } \\
210\end{array}$ & "H"abu & txP4 & rt. & 25.3 & 22.8 & & & 51.7 & 0 & 0 & 0 & 0 & \\
\hline $\begin{array}{l}\text { AUH } \\
1695\end{array}$ & $\begin{array}{l}\text { H. sp. } \\
\text { sm }\end{array}$ & astragalus & lt. & 50.6 & 47.1 & $\begin{array}{l}21 . \\
4\end{array}$ & $\begin{array}{l}41 . \\
3\end{array}$ & 35.3 & 26.7 & $\begin{array}{l}36 . \\
1\end{array}$ & & & \\
\hline $\begin{array}{l}\text { AUH } \\
261\end{array}$ & $\begin{array}{l}\text { H. sp. } \\
\text { sm }\end{array}$ & tmp4 & lt. & & & $\begin{array}{l}11 . \\
9\end{array}$ & 6.8 & 7.8 & & $\begin{array}{l}11 . \\
1\end{array}$ & & $\begin{array}{l}10 . \\
8\end{array}$ & $\begin{array}{l}54 . \\
3\end{array}$ \\
\hline $\begin{array}{l}\text { AUH } \\
397 b\end{array}$ & $\begin{array}{l}\text { H. } s p . \\
s m\end{array}$ & txM3 & rt. & 18.6 & 19.3 & $\begin{array}{l}13 . \\
3\end{array}$ & $\begin{array}{l}15 . \\
8\end{array}$ & 38.1 & & & & & 6.0 \\
\hline
\end{tabular}


Fig. 16.1

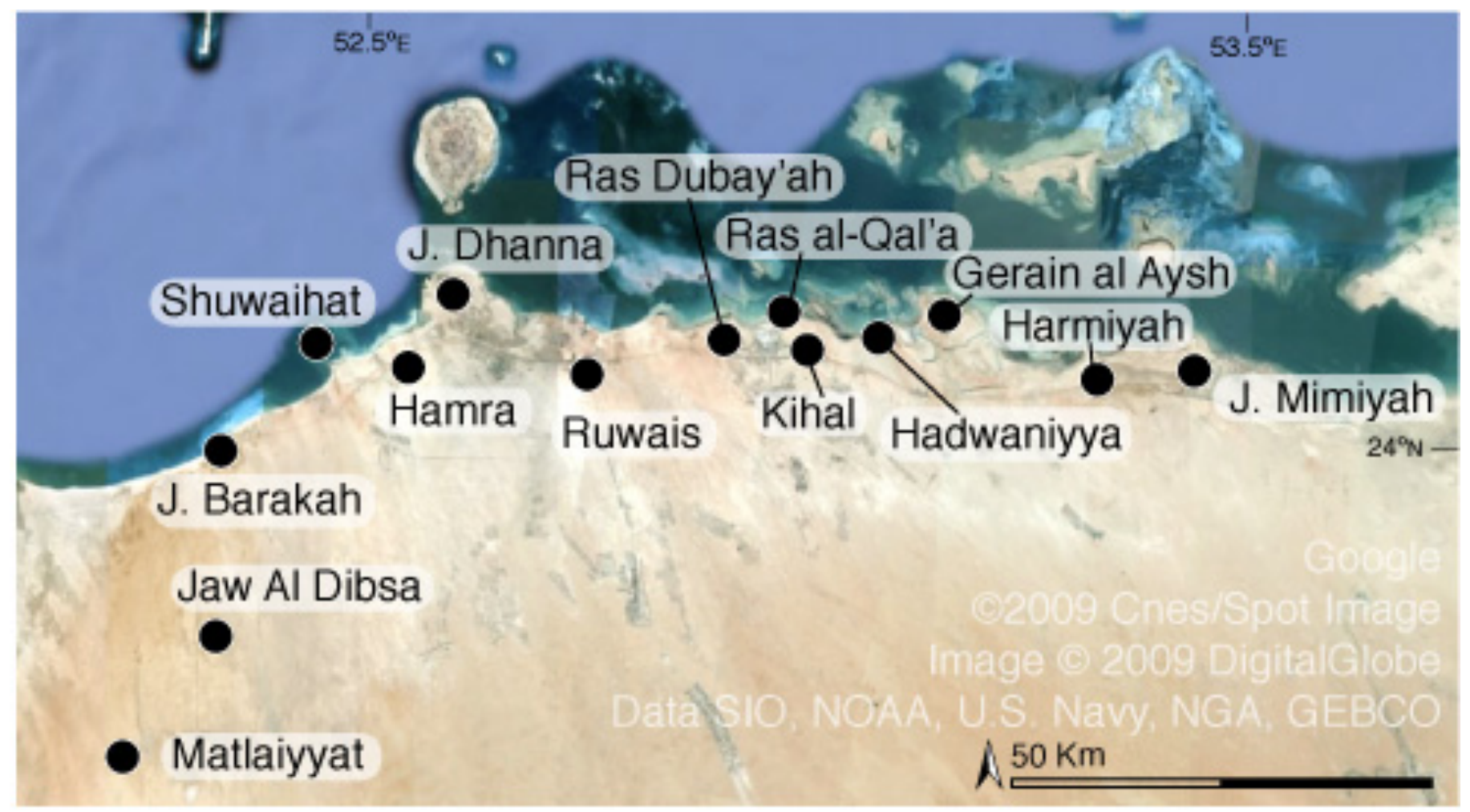


A

\section{CALCANEUM}

Fig. 16.2
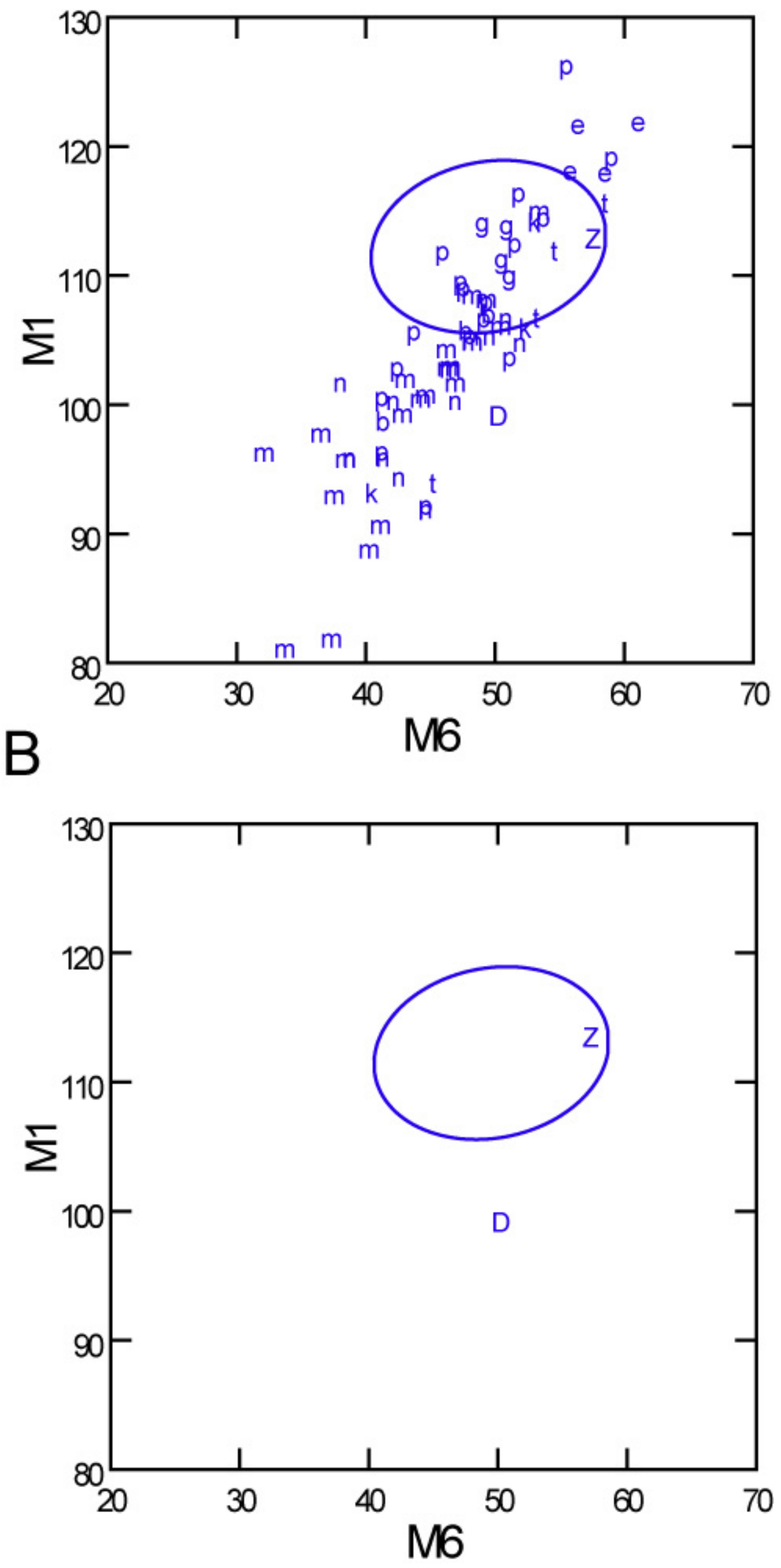
A

ASTRAGALUS

Fig. 16.3
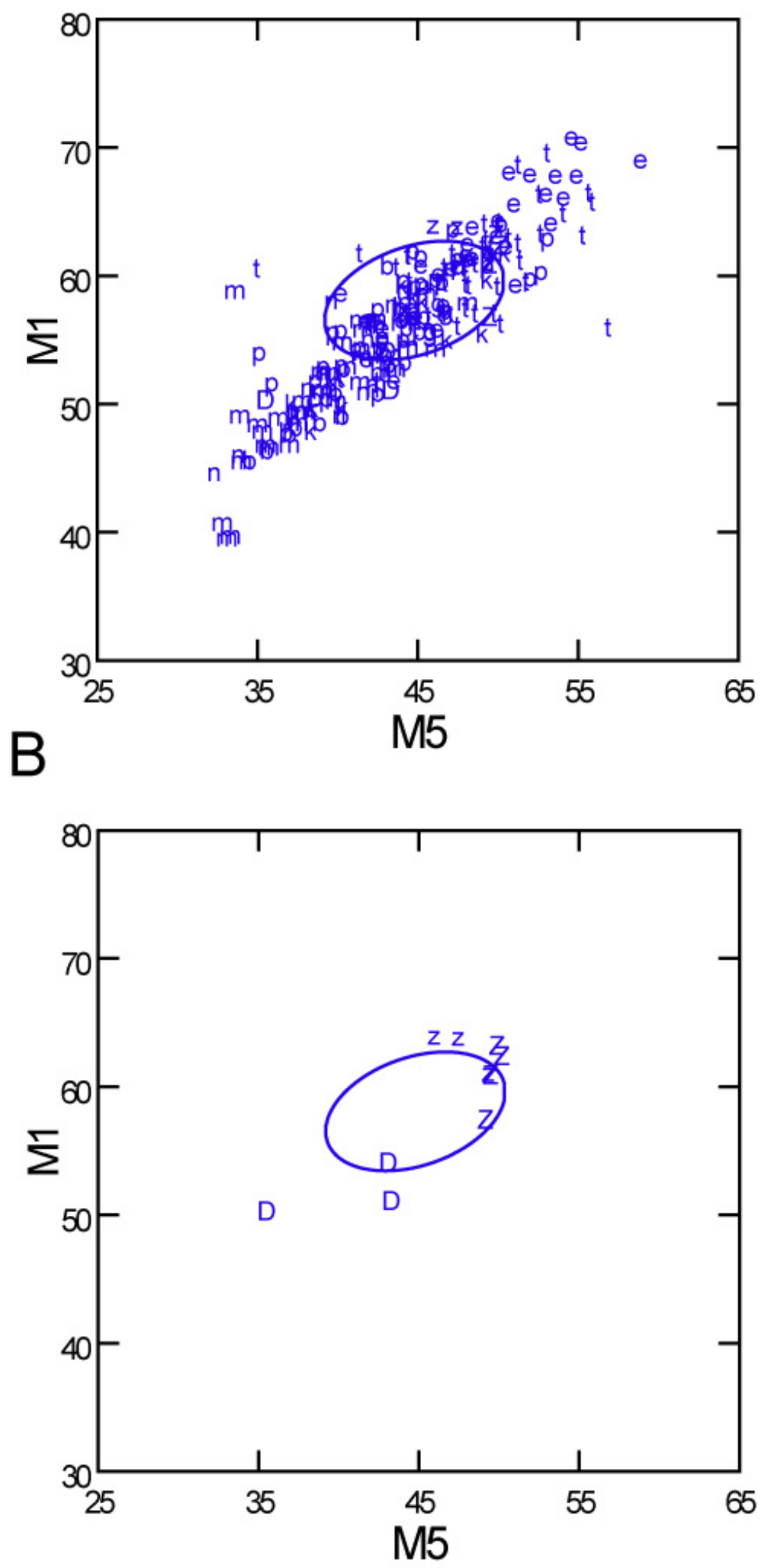
Fig. 16.4

A

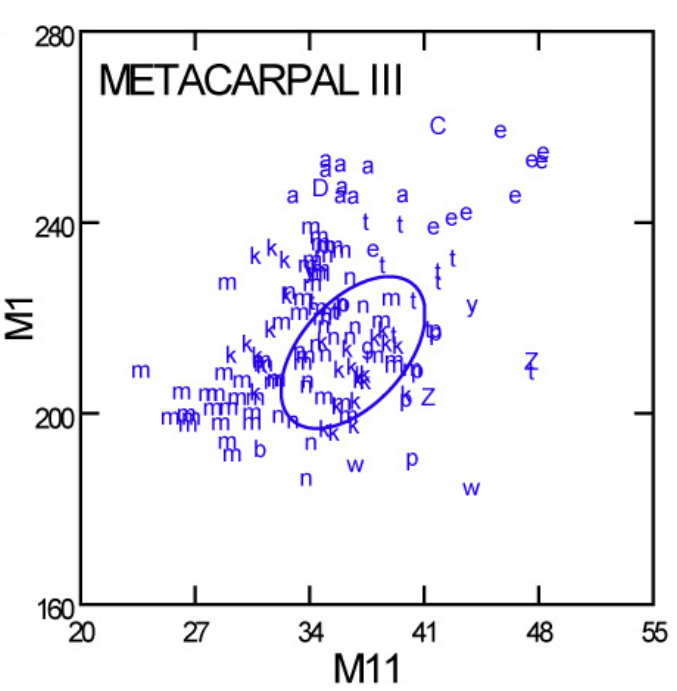

B
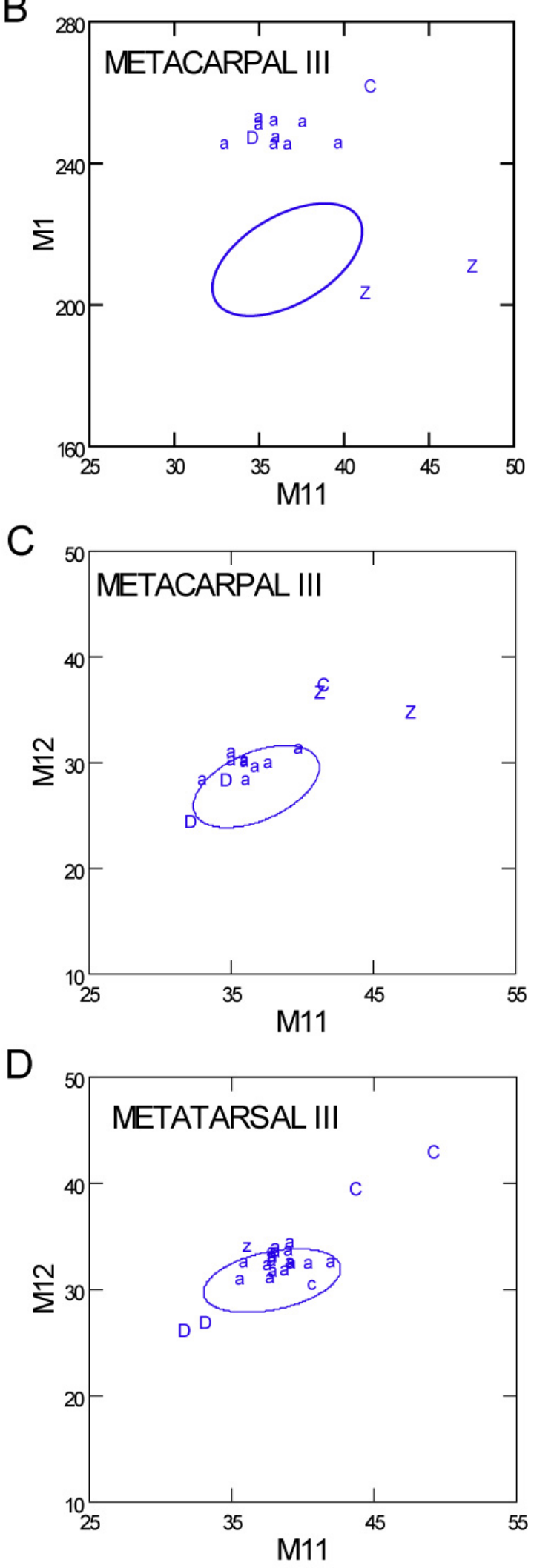
A

1stPHIII

Fig. 16.5
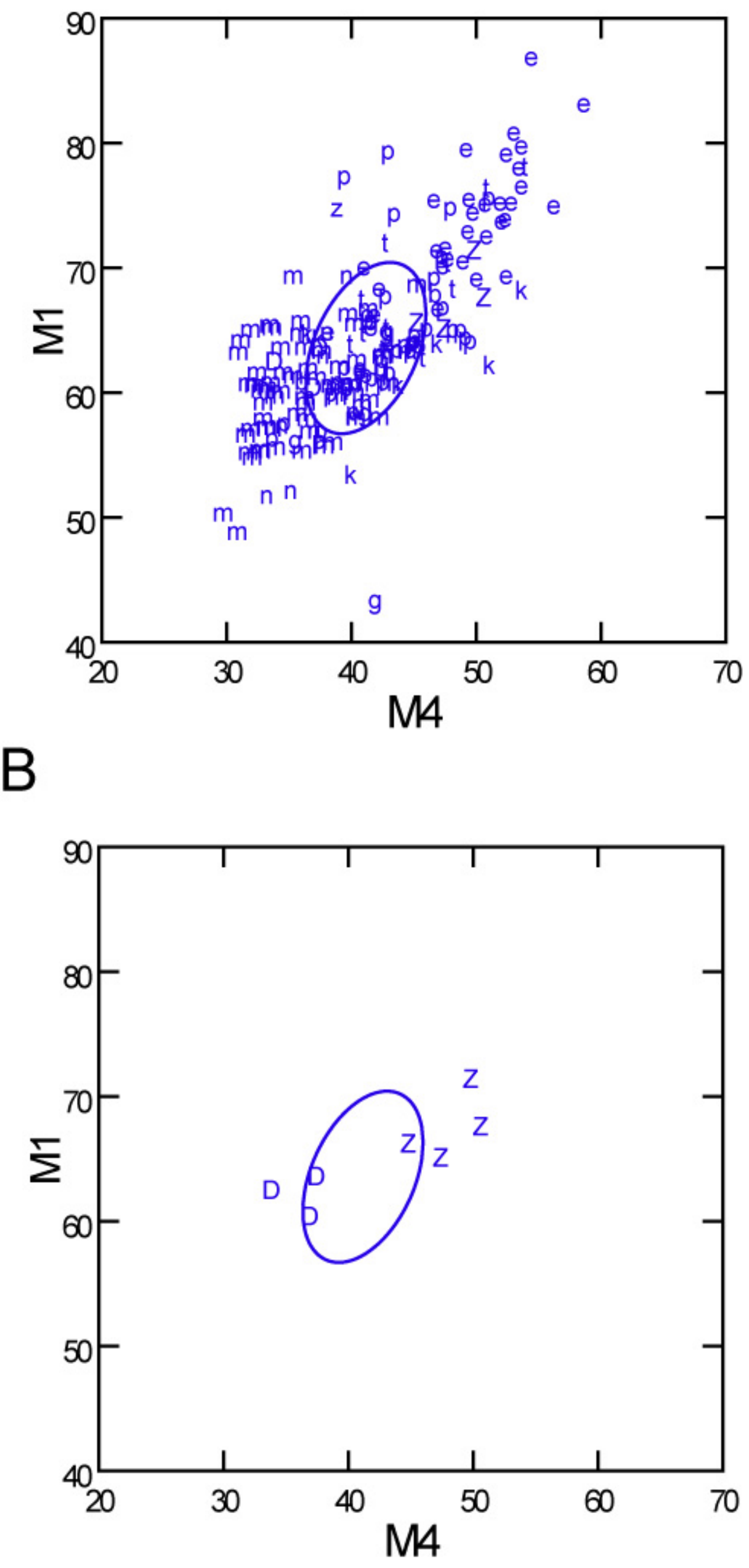
Fig. 16.6
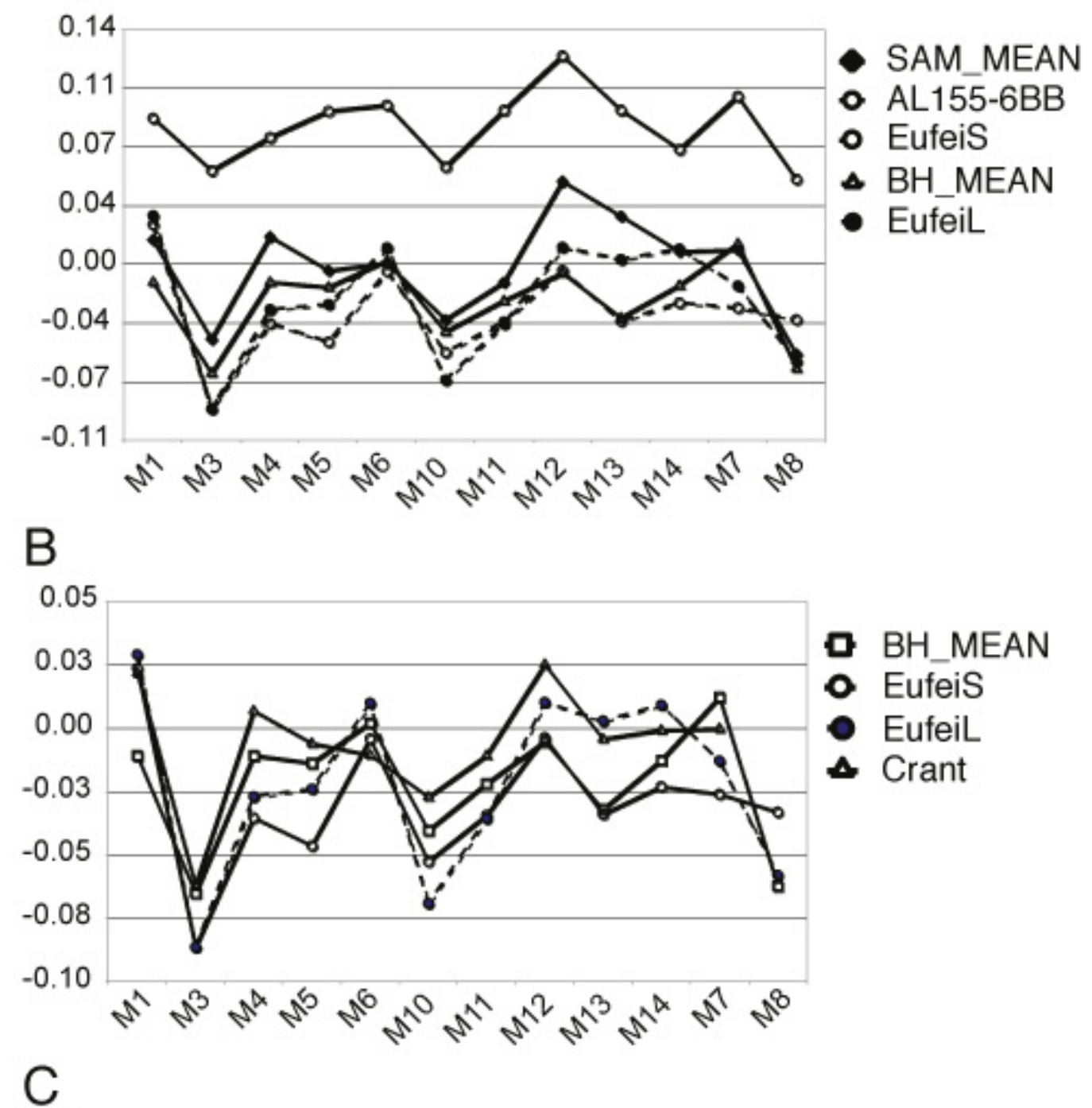

- BH_MEAN

- EufeiS

- Eufeil

^ Crant

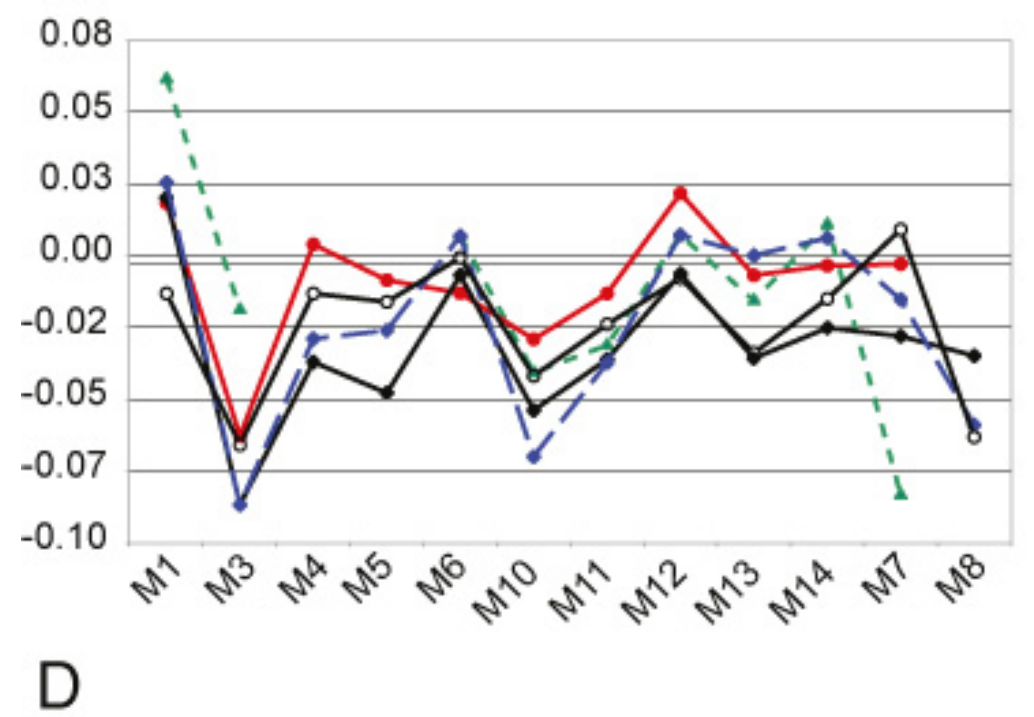

- BH_MEAN

- EufeiS

- AUH 1499

- Eufeil

- Crant

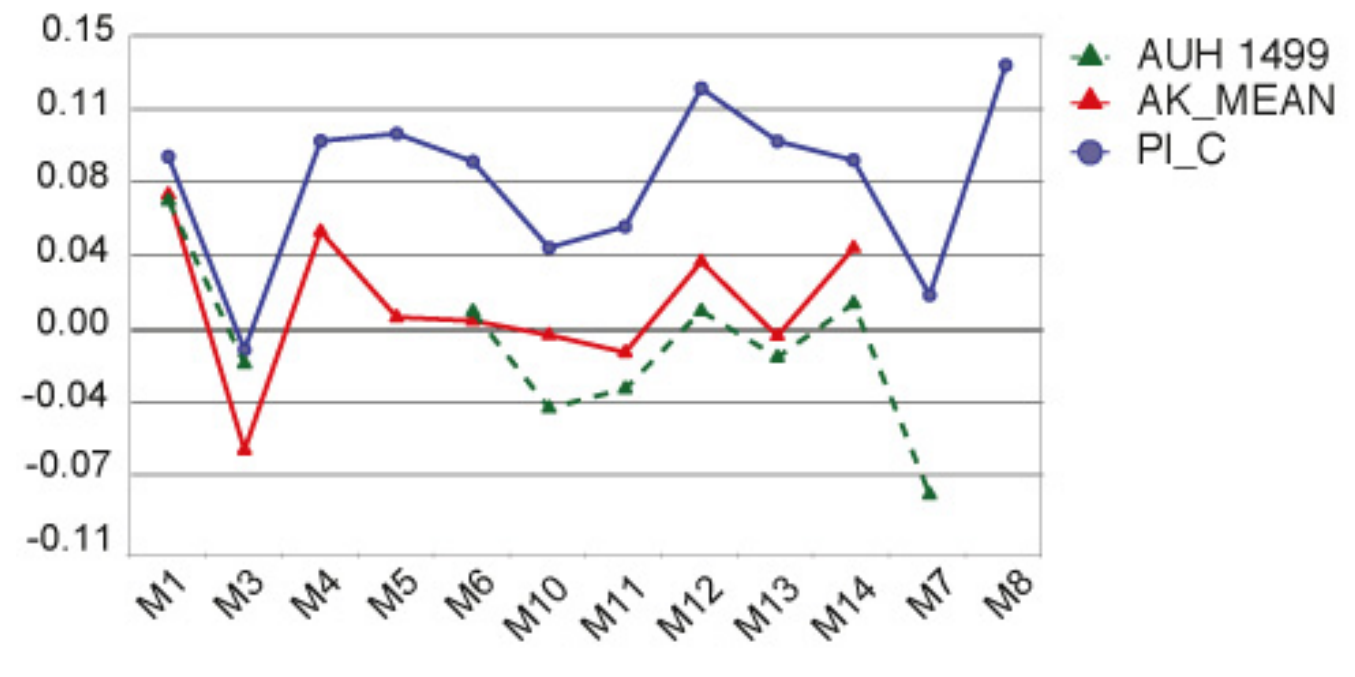


A

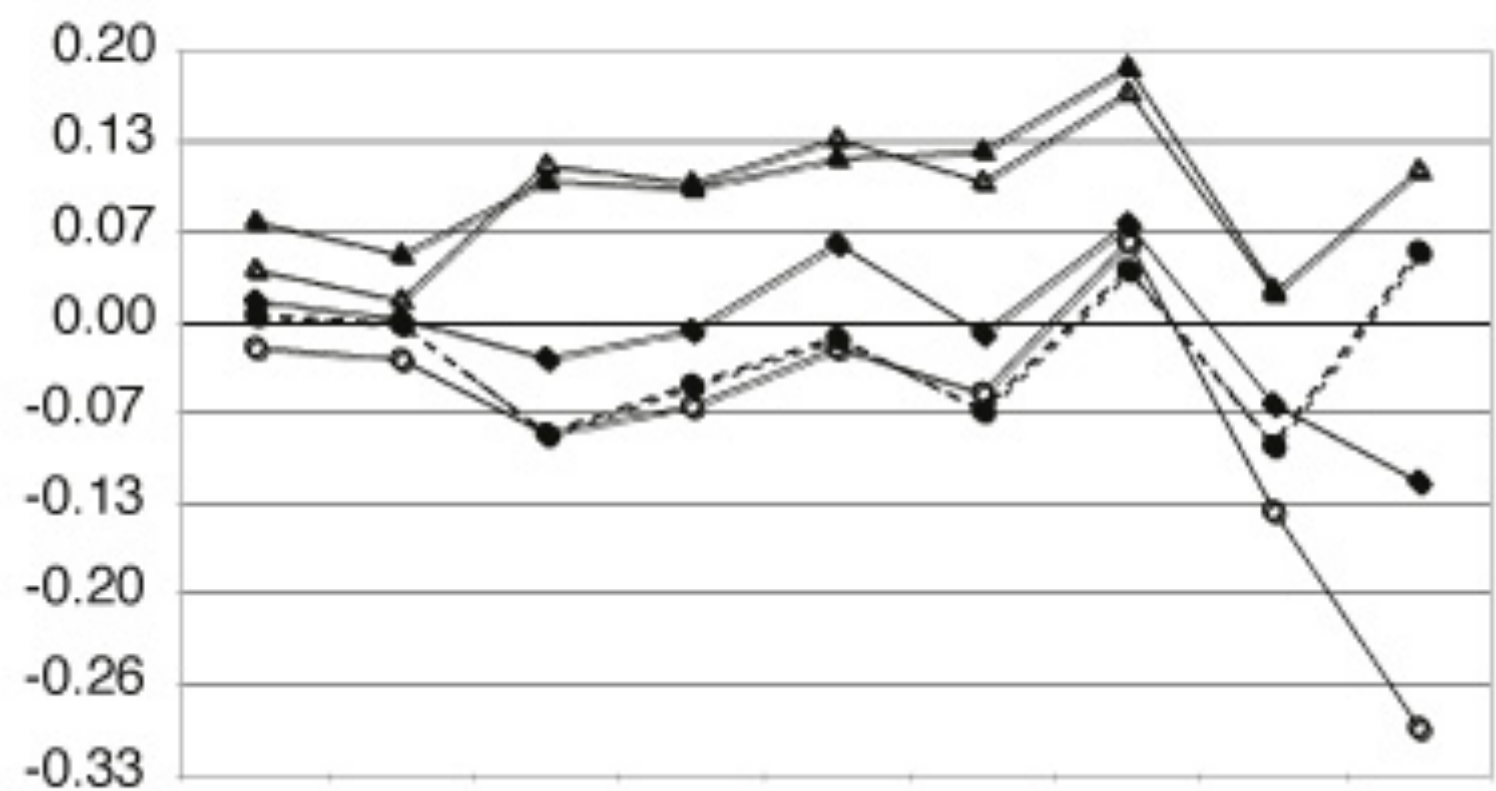

- Euhoo_MEAN

* AL155-6X

- EufeiS

$\triangle$ AL155-6AR

- Eufeil

B

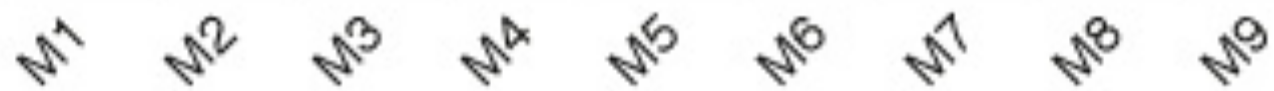

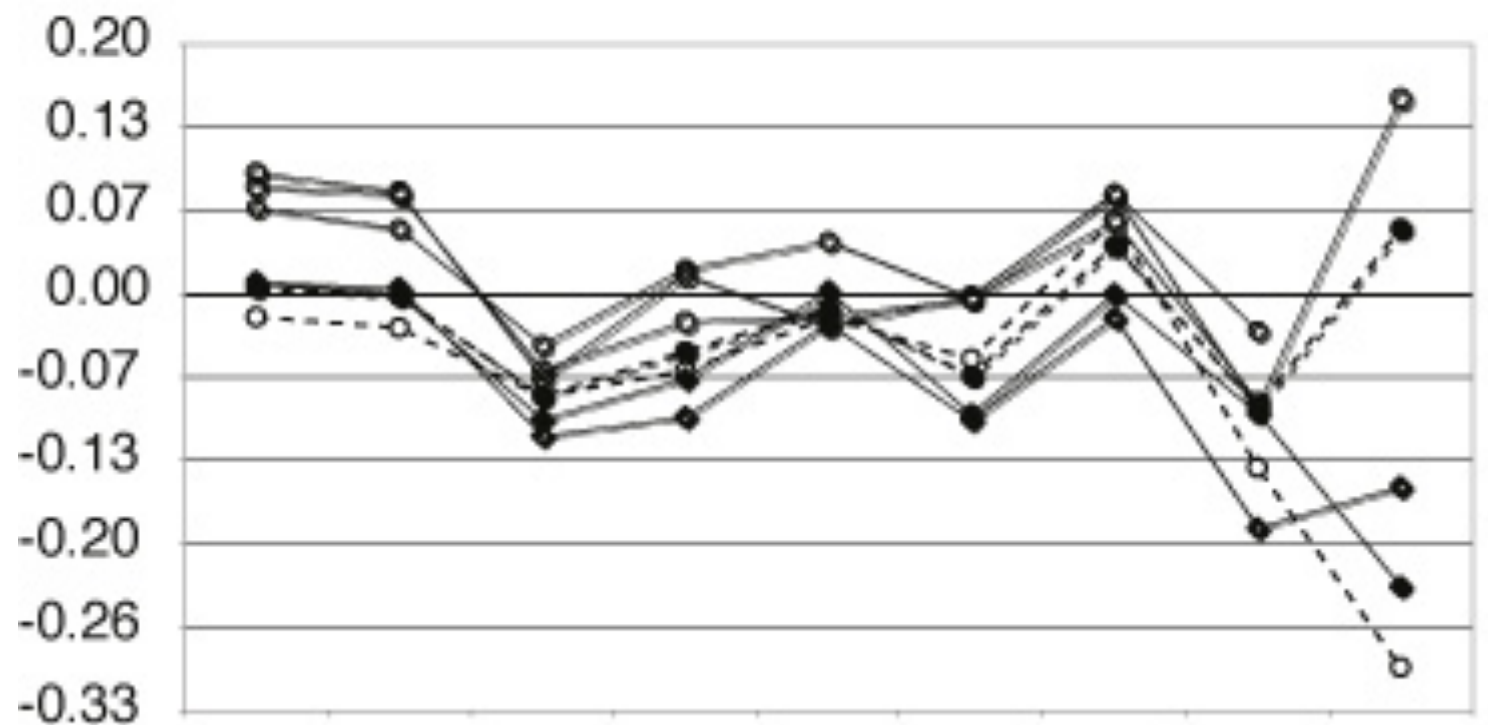

- Eufeil

- MMTT13/2457

- BMNH M17430

- BMNH M2662

- EufeiS

- MMTT13/RLB44

- BMNH M2661

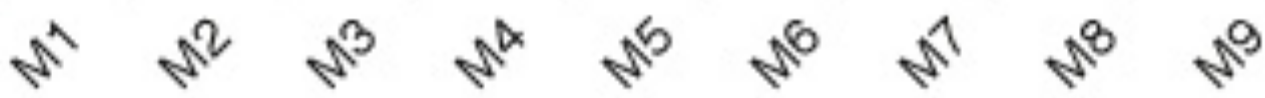

$\mathrm{C}$
0.20
0.13
0.07
0.00
$-0.07$
$-0.13$
$-0.20$
$-0.26$
$-0.33$

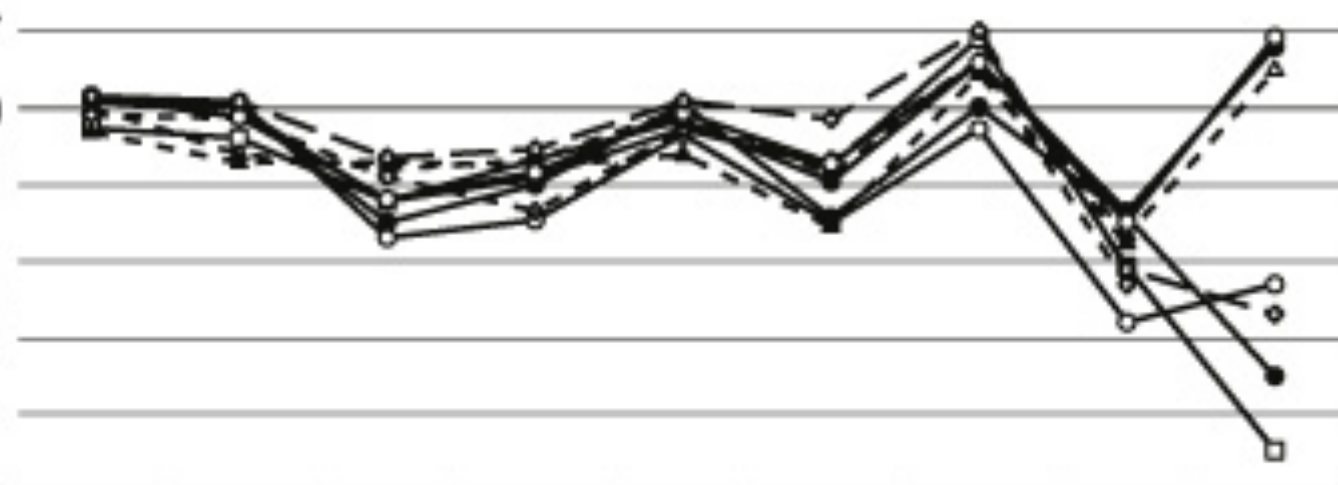

$\diamond$ EufeiMA

- Eufeil

- MMTT13/2457

- AUH 1279

$\triangle \mathrm{AUH} 324$

。 KNM-LT 25472

a Eufeis

- MMTT13/RLB44

$\diamond$ AUH 1765 
Fig. 16.8

A

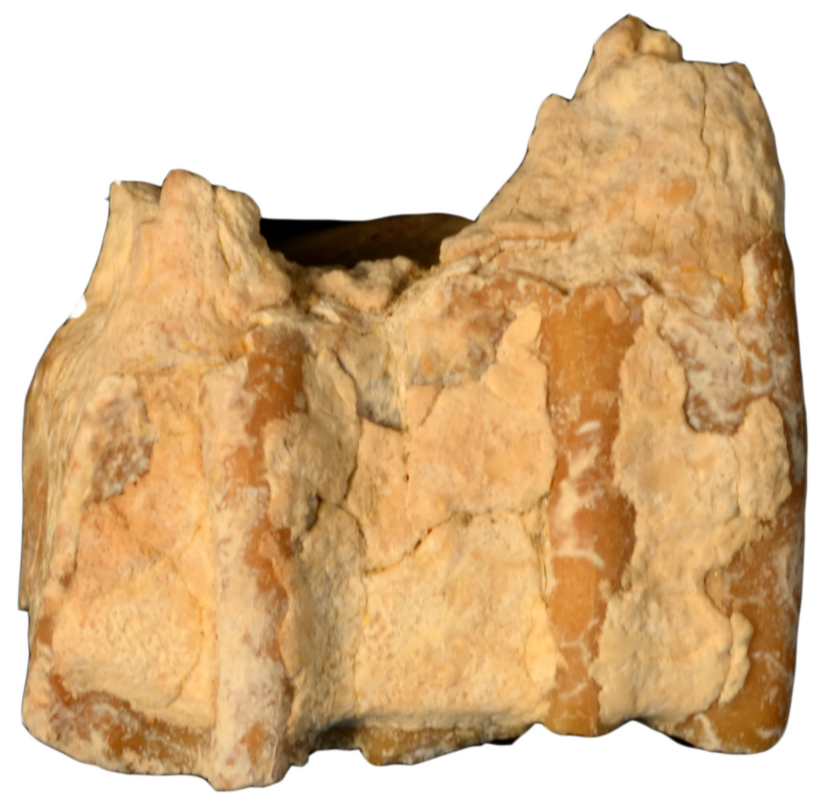

B

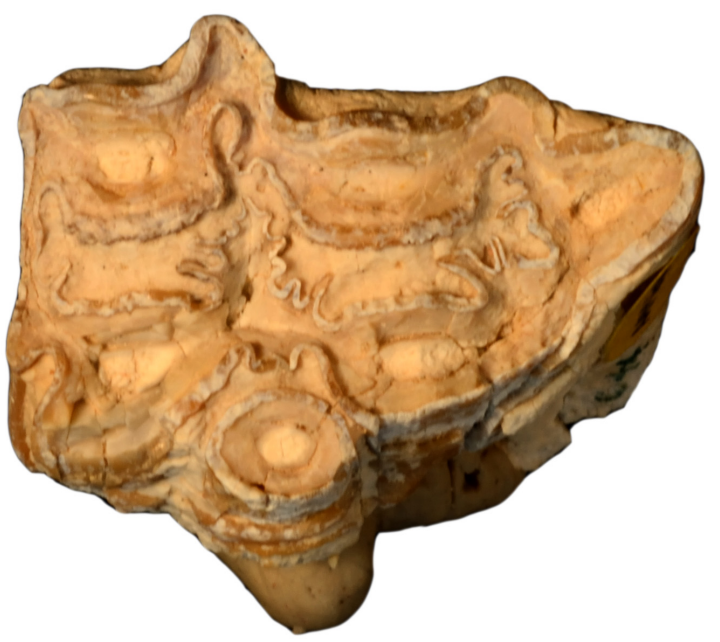

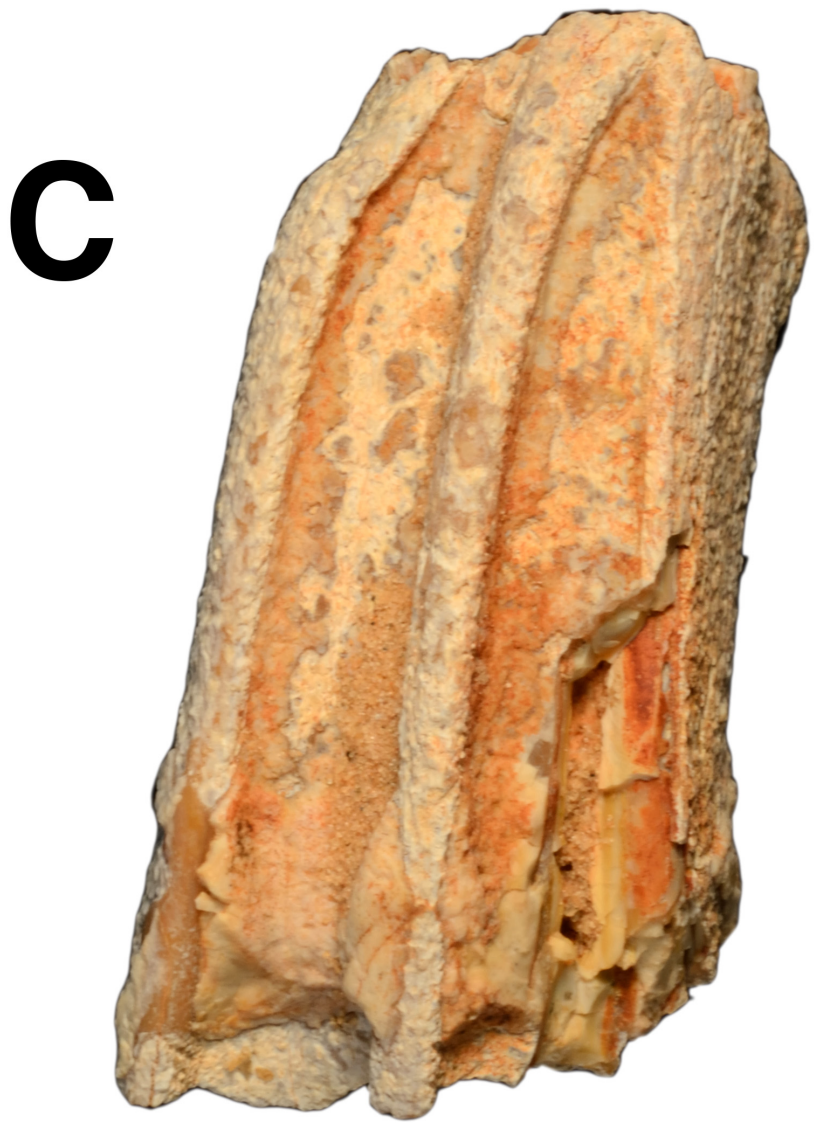
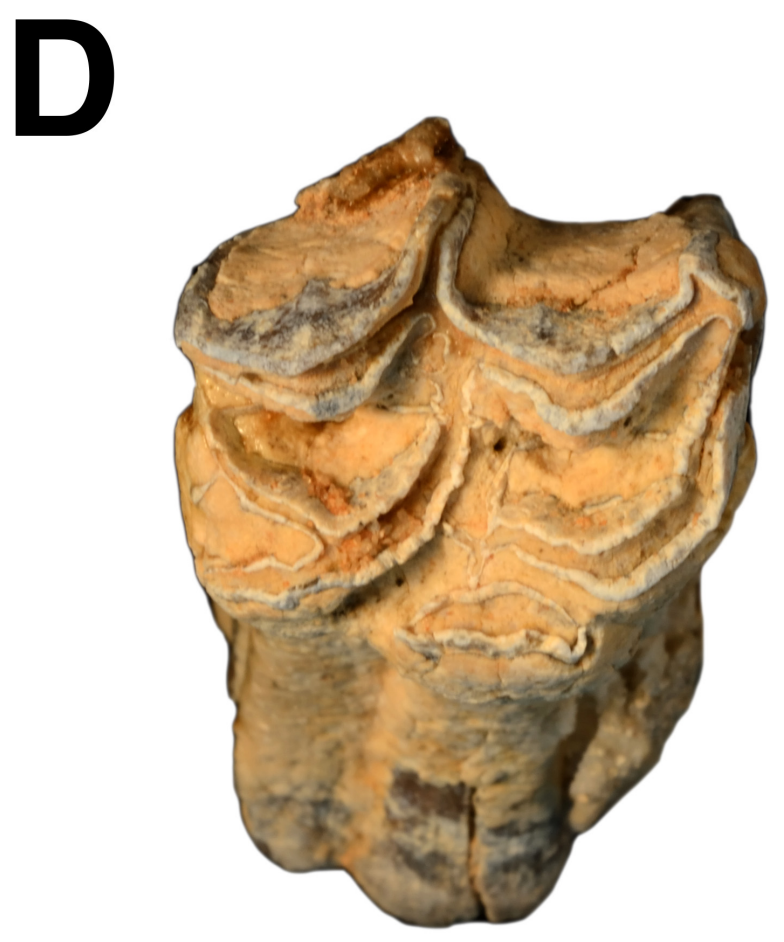

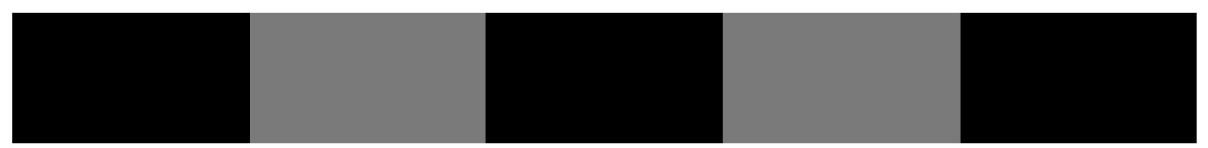



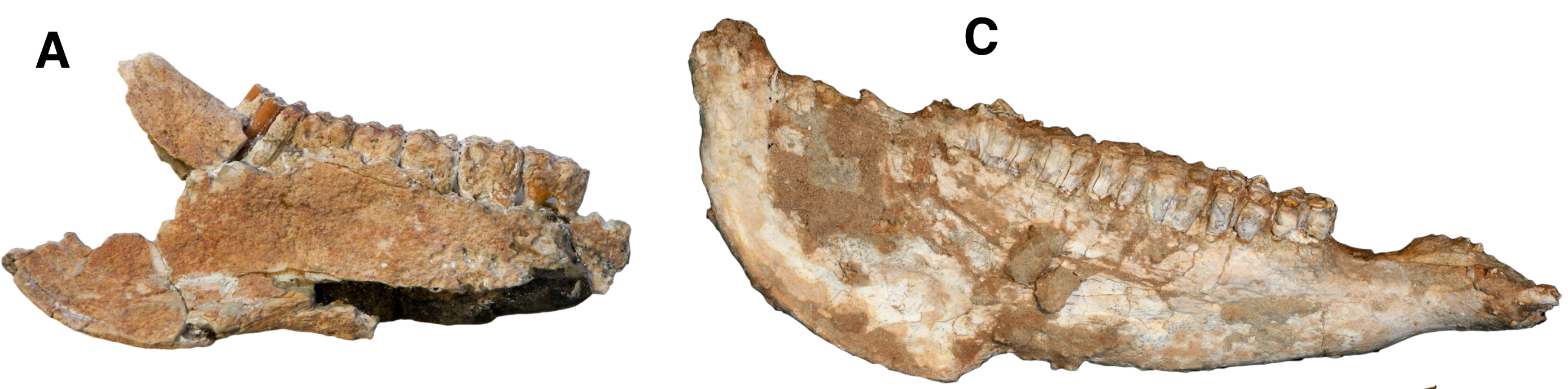

B
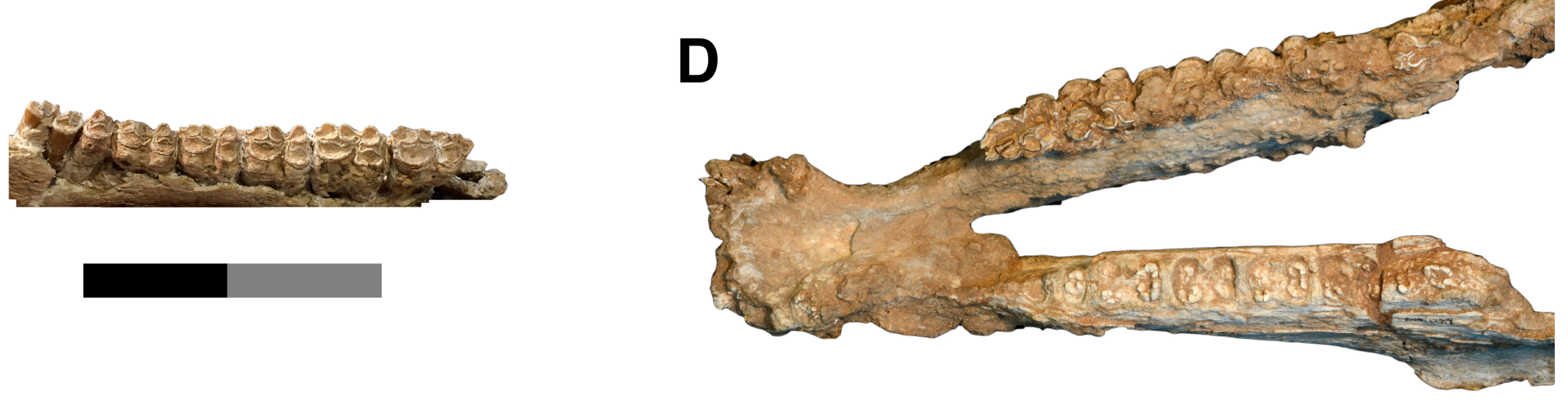
A

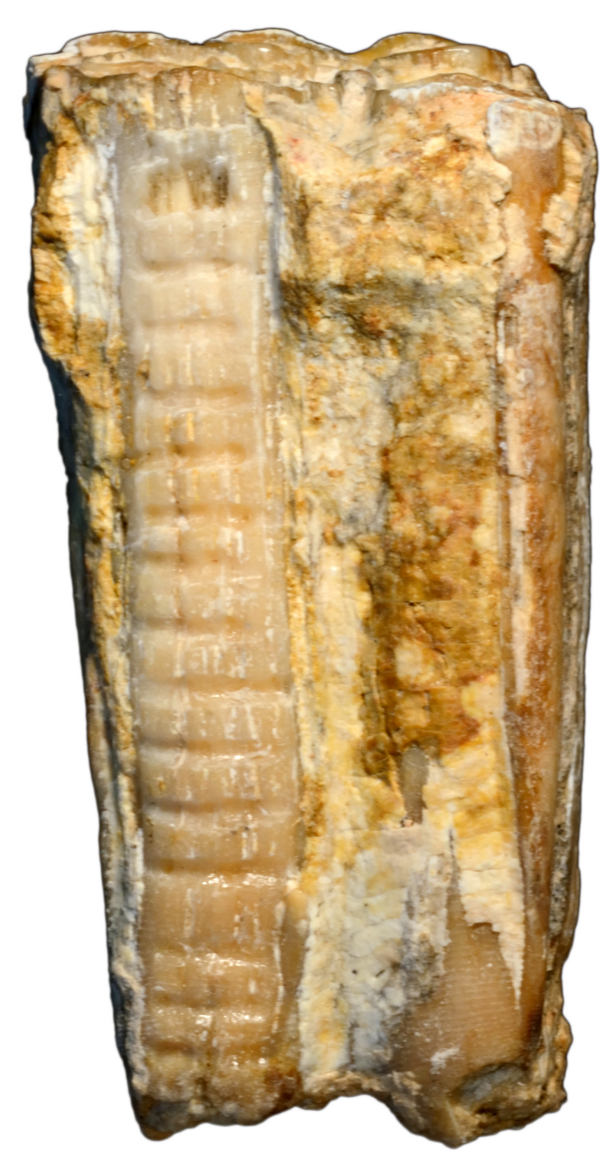

B

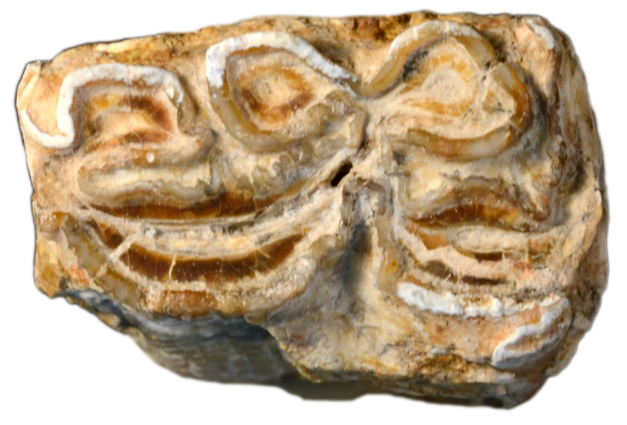

C

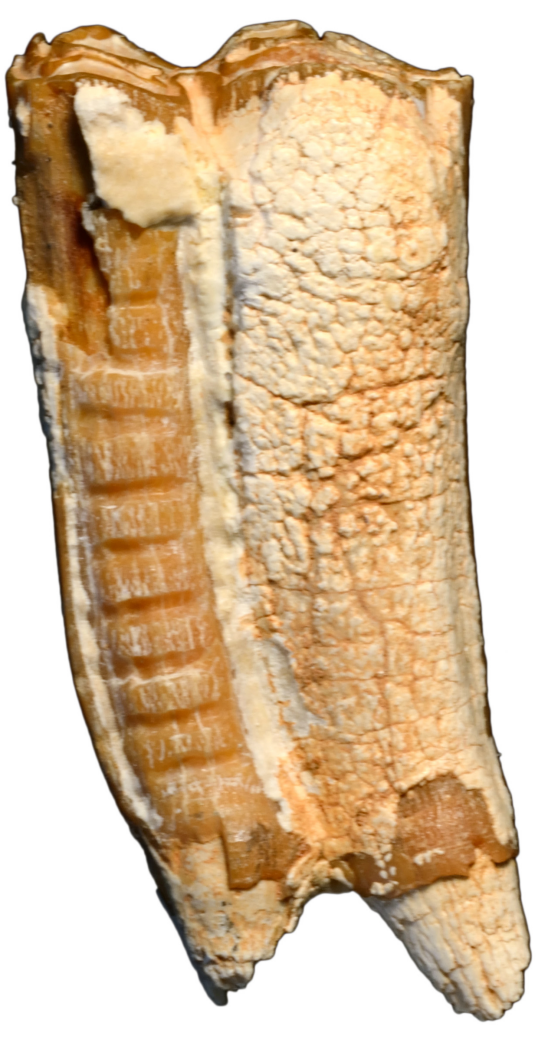

D

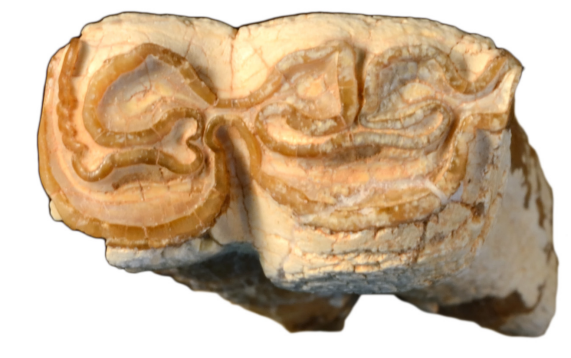

E

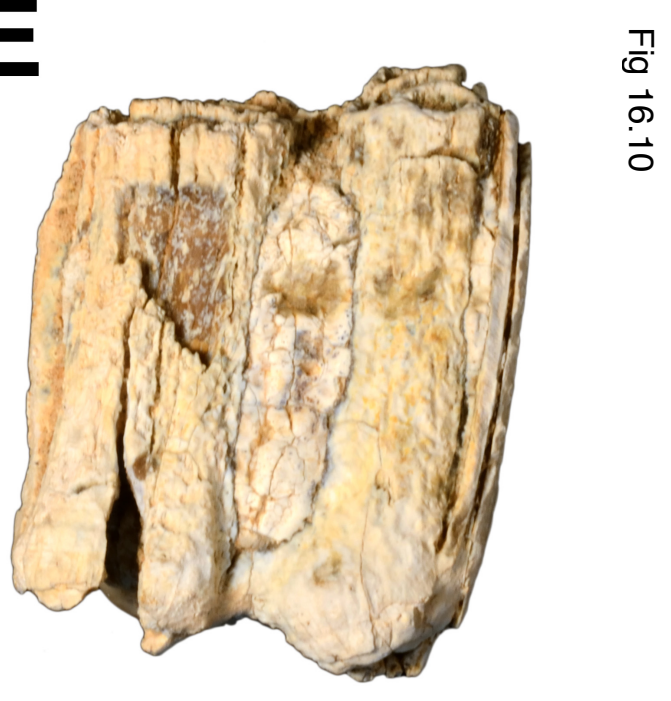

F

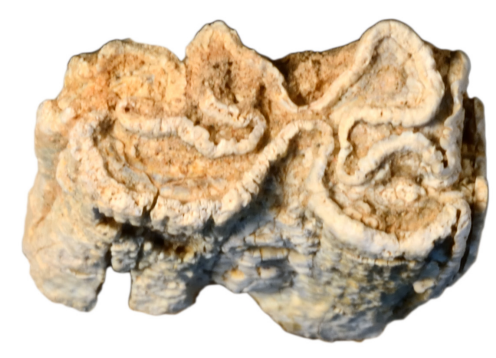

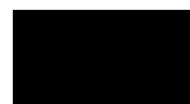
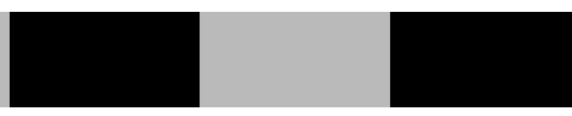
Fig. 16.11

A

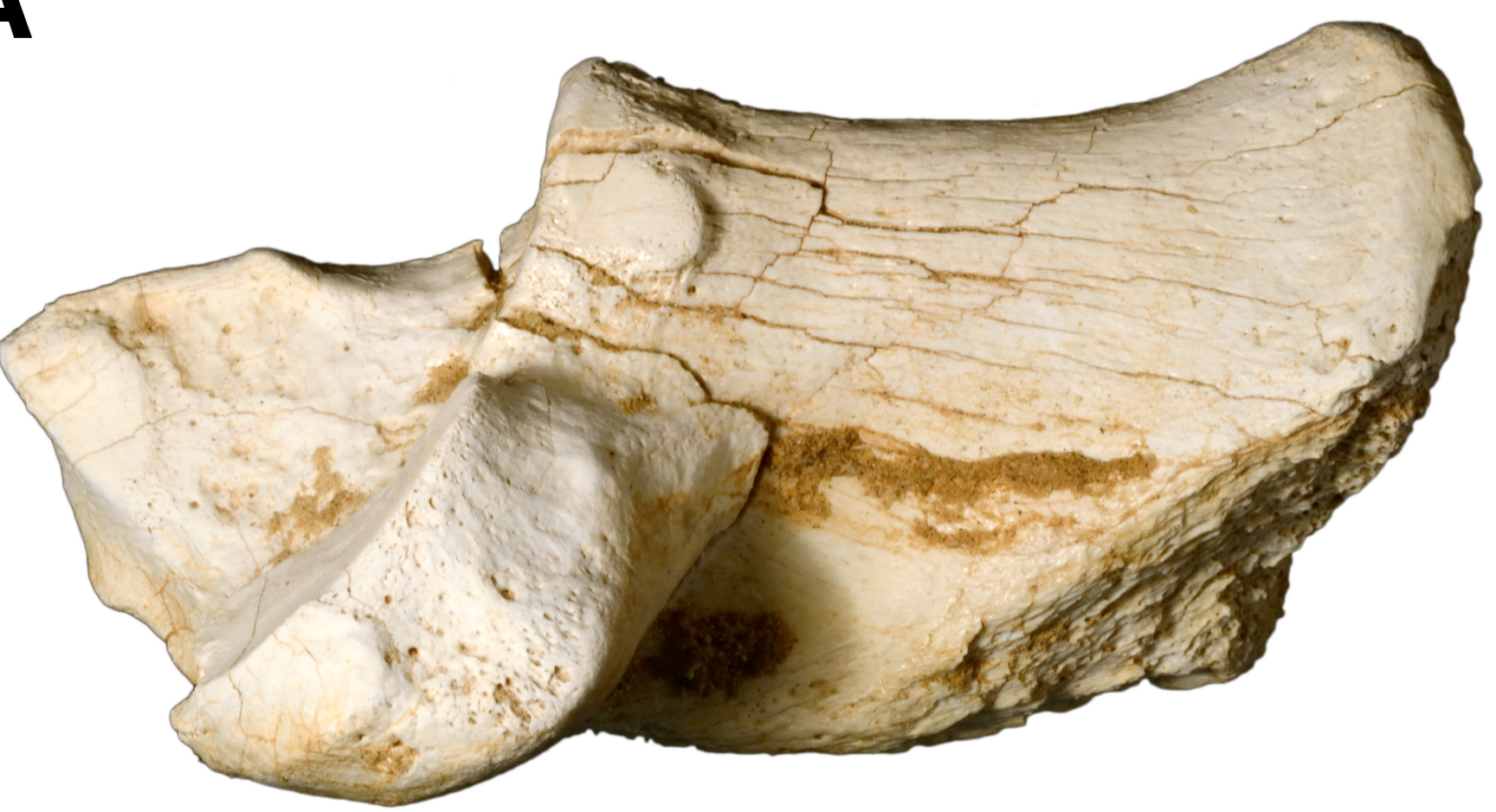

B

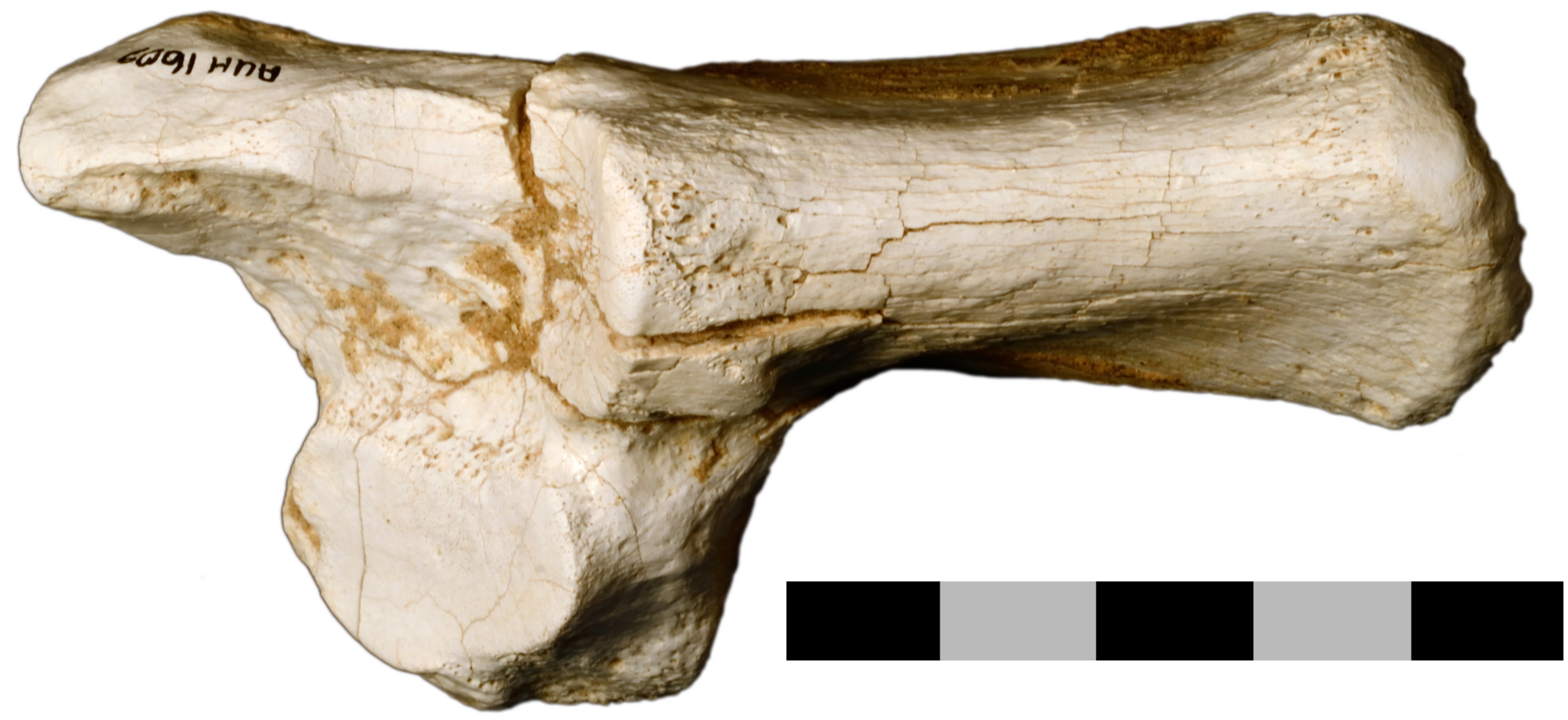


Fig. 16.12

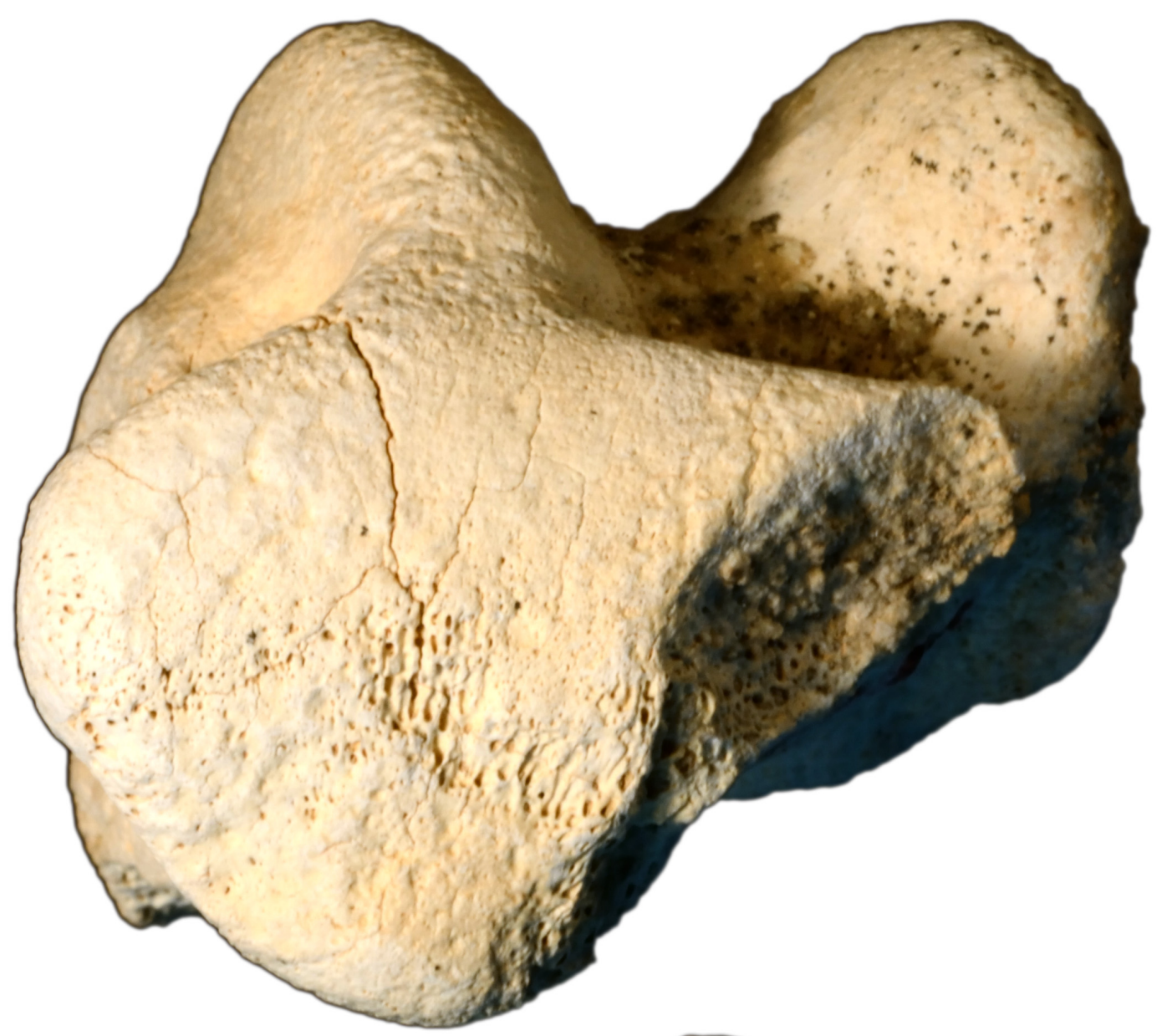

B
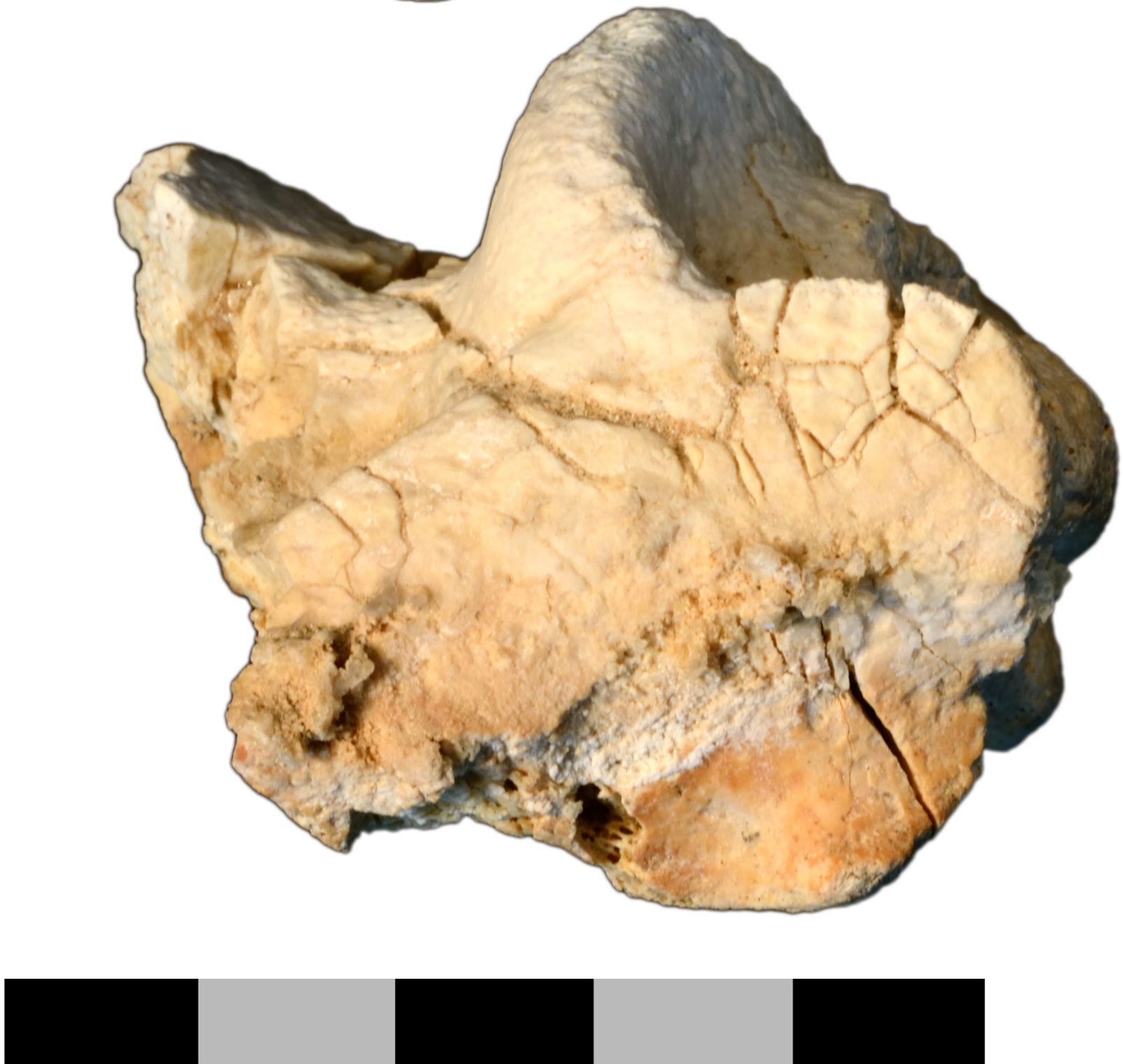


\section{A}

Fig. 16.13

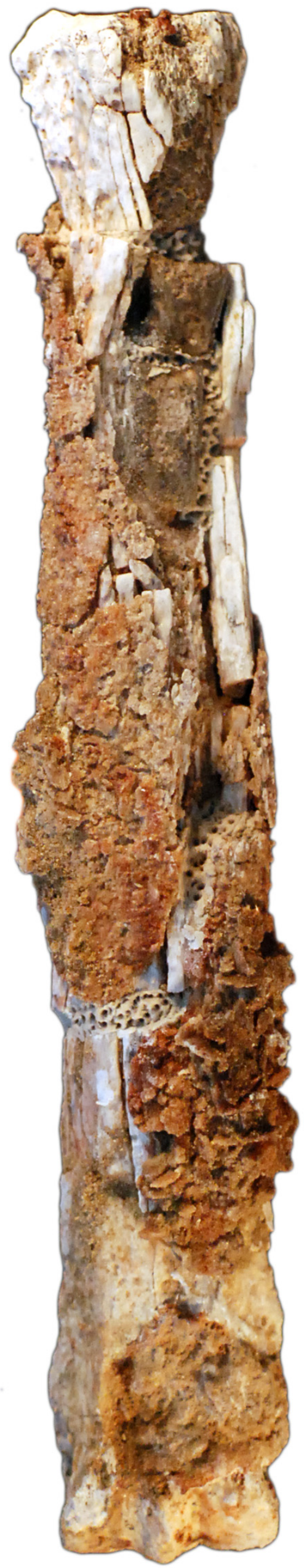

B

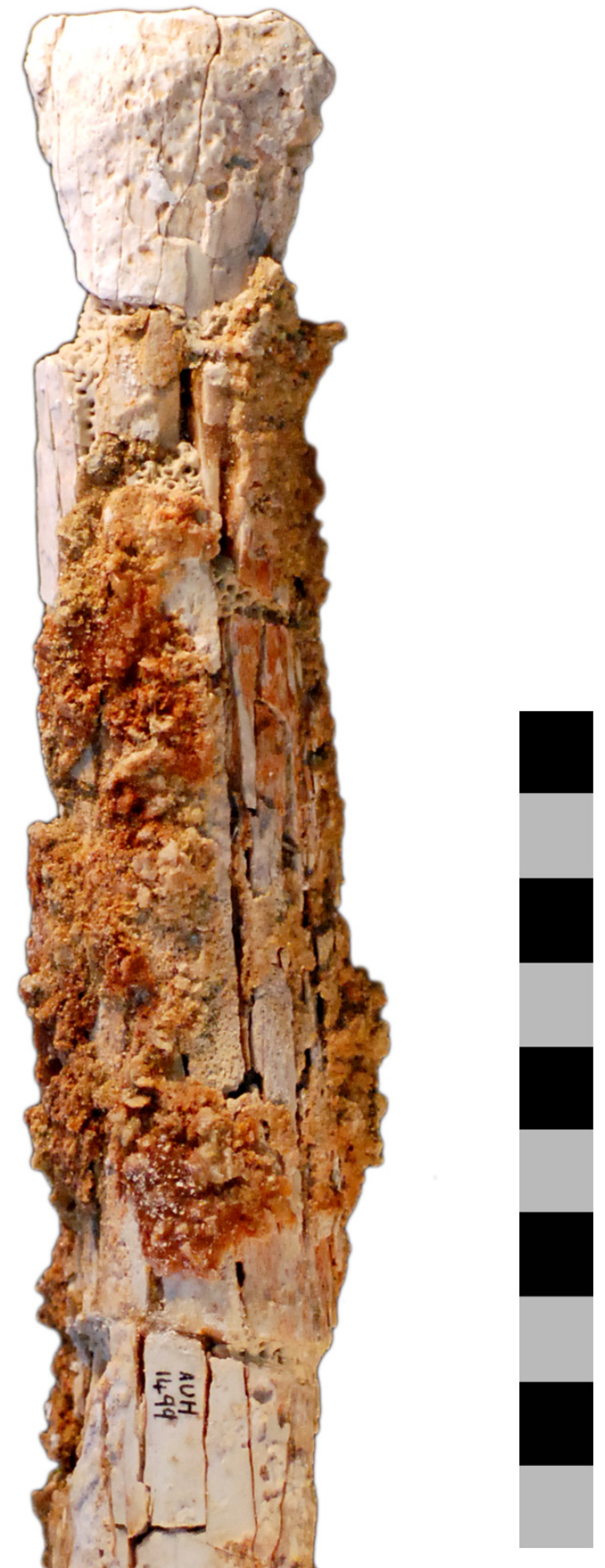


Fig. 16.14

A

B
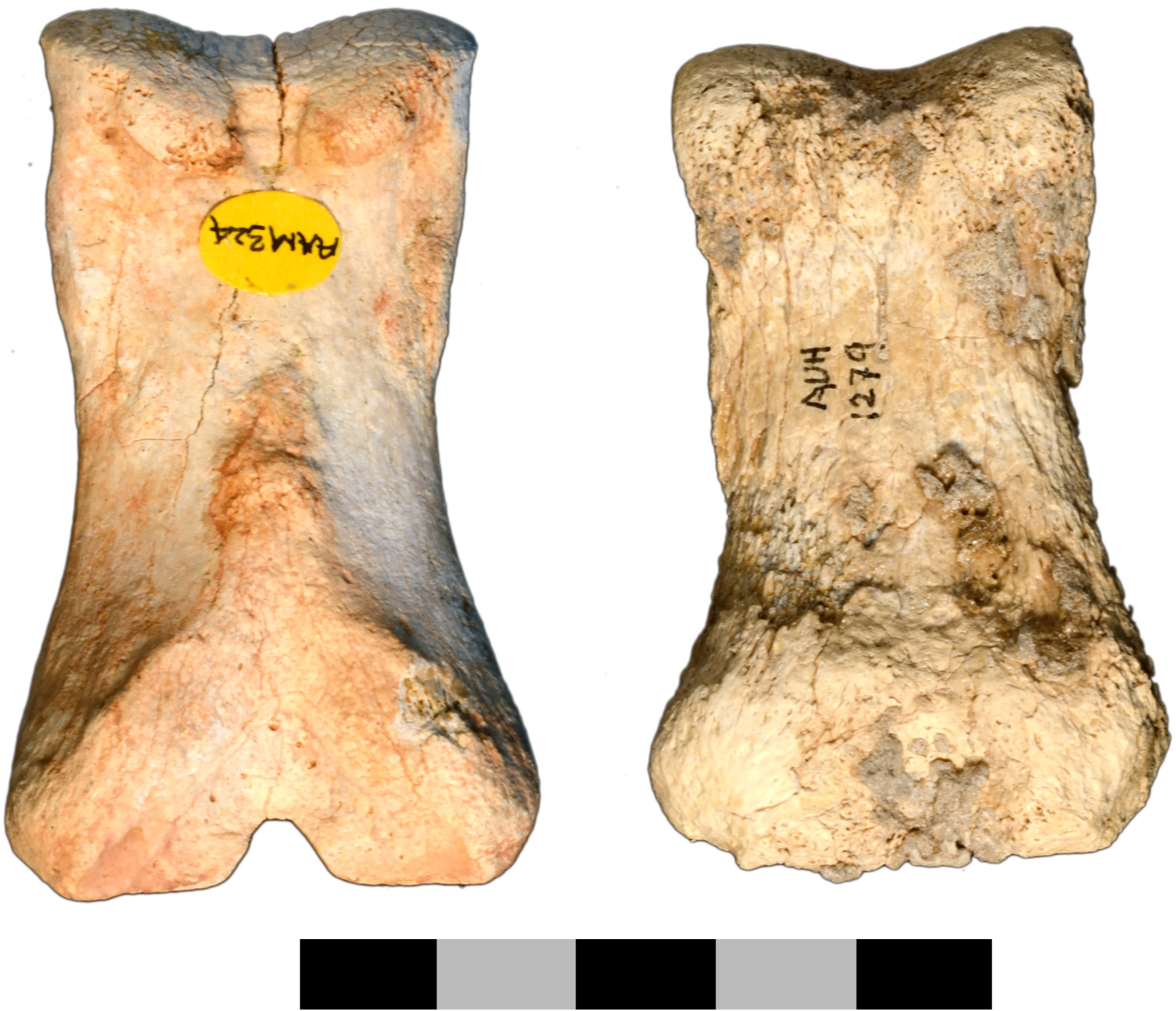

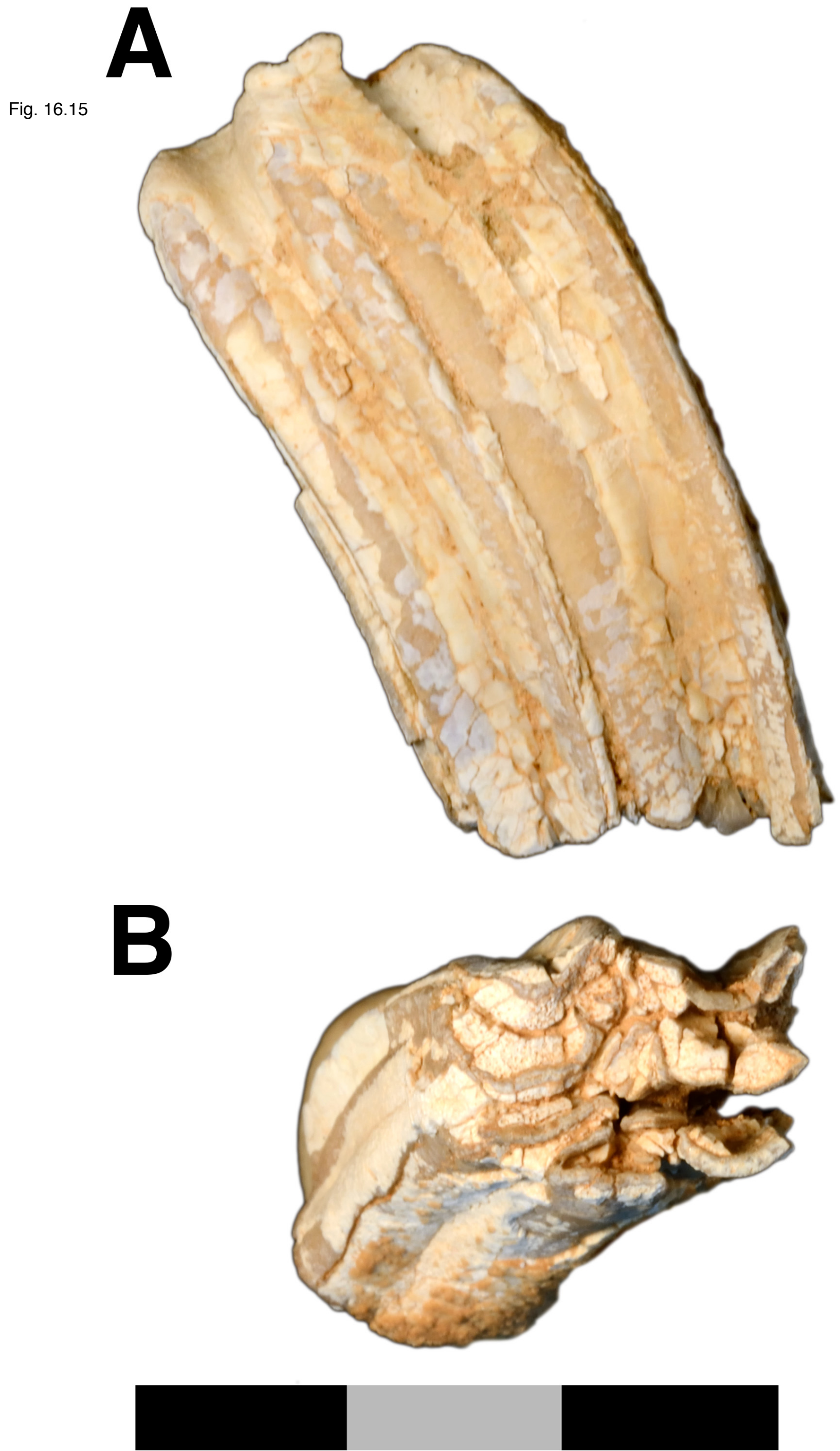
Fig. 16.16
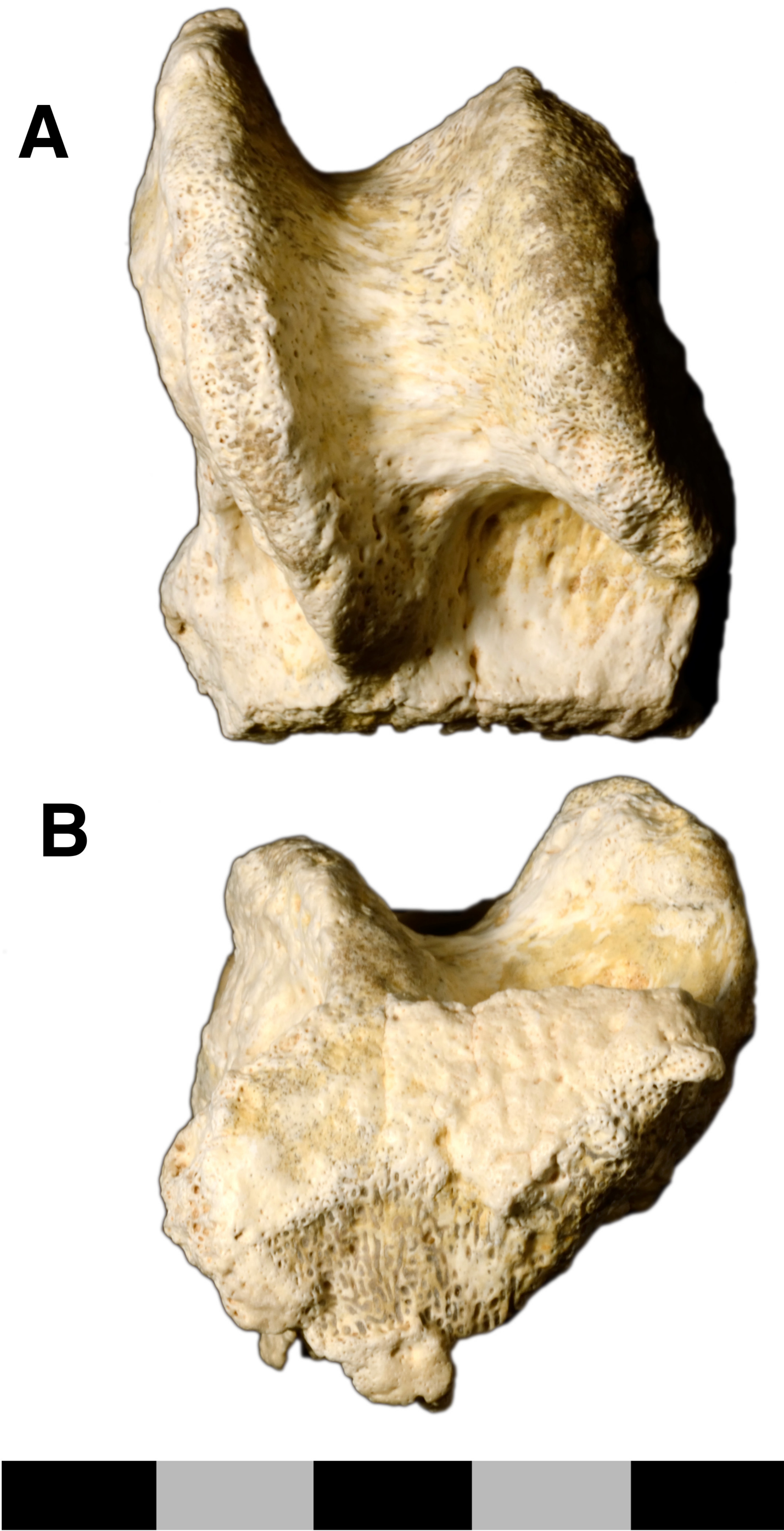
Fig. 16.17

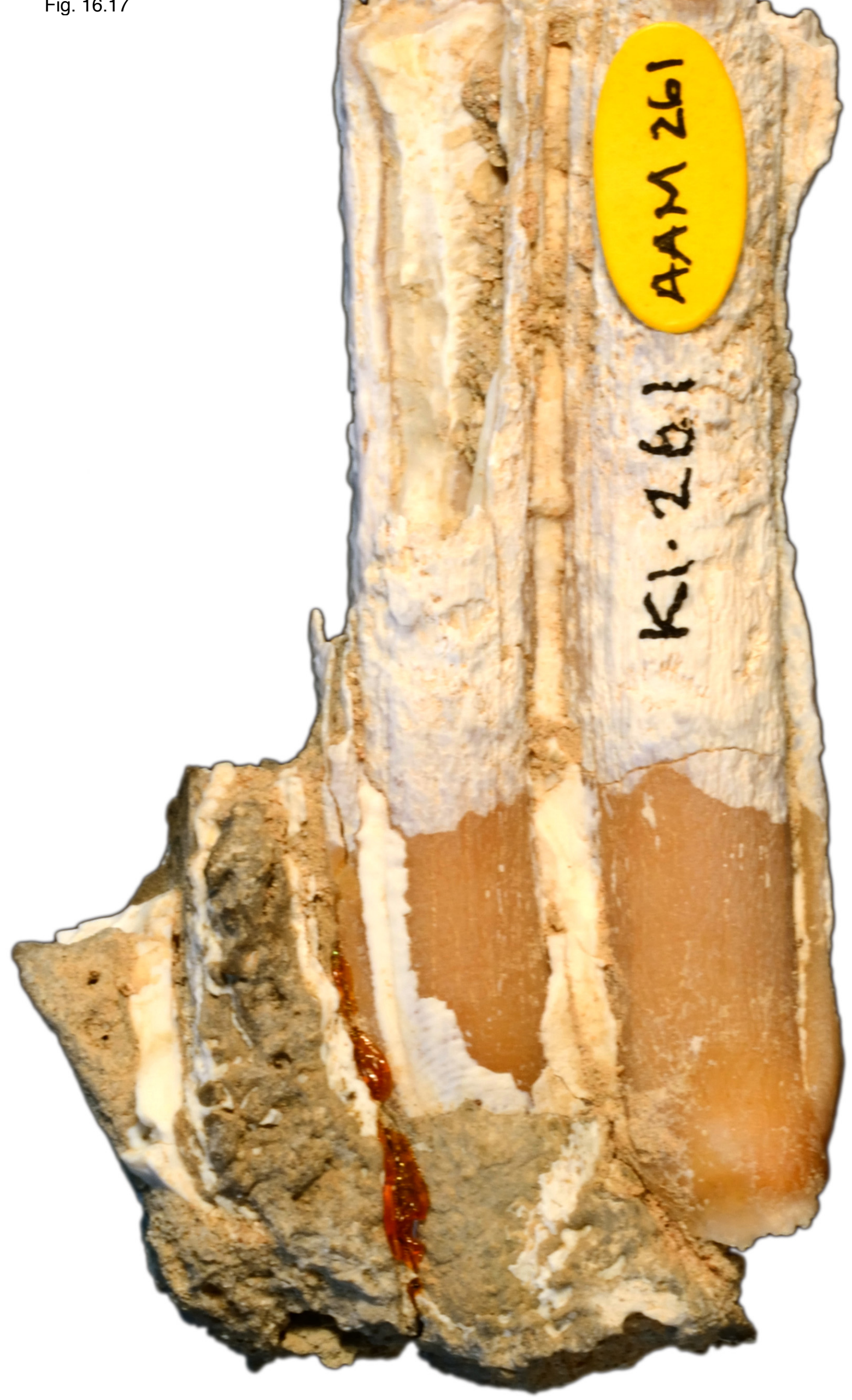

